\title{
Kemoterapötiklerin erkek üreme sistemi üzerindeki yan etkileri ve koruyucu stratejiler
}

\author{
Gaffari Türk1
}

ÖZET: Sitotoksik kemoterapi pek çok kanser türünün tedavisinde etkili bir yöntem olmasına rağmen organizmada sayısız yan etkilere neden olmaktadır. İnfertilite de kemoterapötik ilaçların hem erkek hem de dişilerde meydana getirdiği en önemli yan etkilerden biridir. Cinsel isteksizlik, oligo-, azoo-, astenozoo- ve teratozoo-spermi, testiküler yapı, spermatogenesis ve steroidogenesisteki bozukluklar, gonadotropin düzeylerindeki değişiklikler, sperm DNA ve kromozomlarındaki hasarlar ve hatta tam sterilite hem kanserli erkekler hem de sağlıklı deney hayvanlarında bildirilen kemoterapi kaynaklı yan etkilerdir. Kemoterapötiklerin erkeklerdeki gonadotoksik etkilerinin önlenmesine yönelik hormon ve antioksidan uygulamalar ile sperma ve germ hücrelerinin dondurularak saklanması gibi birtakım yöntemler kullanılmaktadır. Bu derlemede kanser tedavisinde yaygın olarak kullanılan kemoterapötiklerin kanserli ve sağlıklı erkeklerin üreme organ, doku ve hücrelerinde meydana getirdiği yan etkiler ve bu etkilerin azaltılması veya önlenmesine yönelik koruyucu stratejiler ile ilgili literatür bilgiler sunulmaktadır.

ANAHTAR KELIMELER: Antioksidan; kemoterapötik; kriyoprezervasyon; oksidatif stres; sperm; testis

\section{GiRiş}

Kanser, vücuttaki dokulardan birine ait bir veya birkaç hücrenin normal özelliklerinin dışında bir değişim göstermesi ve kontrolsüz çoğalması ile meydana gelen ve genellikle tümör (kitle) meydana gelmesine sebep olan, çağımızın en önemli hastalıklarından birisidir (1). Hücre içerisinde tümör supresör genlerin (p53, v.b.) mutatik inaktivasyonu ve bölünmeyi kontrol eden genlerin mutasyonu (onkogenlerin aktivasyonu) gibi bir dizi genetik değişiklikler sonucu kanser şekillenmektedir (2). Halen kesin bir tedavisi bulunmamakla birlikte çeşitli kemoterapötik (antikanser) ilaçlar tedaviye yönelik olarak kullanılmaktadır. Kemoterapi, özellikle çoğalan hücrelere karşı seçici öldürücü etkileri olan, doğal veya sentetik kimyasal, biyolojik ajanlar ve hormonlarla yap1lan tedavi şeklidir. 1960'l y yllara kadar kemoterapi palyatif amaçla, bazı klinik bulguların azaltılması ve hastanın yaşamını biraz daha uzatmak amacıyla kullanılmıştır. Ancak 1960'lı yıllardan itibaren hücre kinetiği bilgileri ve kinetik kavramları kemoterapi protokollerinde uygulanmaya başlanılmıştır. Hücre kinetiği hakkında bilgiler arttıkça yeni ilaçlar laboratuvarlarda antikanser aktiviteleri açısından araştırılmaya başlanmıştır (3).

Kemoterapötik ajanlar (Tablo 1) en fazla hücreler proliferatif dönemde iken etkilidirler. Kanserli (neoplastik) hücrelerin normal hücrelere göre hızlı büyümesi ve çoğalması nedeniyle çoğu kemoterapötik ilaç bu tür özellik taşıyan hücrelerin tahrip edilmesi için geliştirilmiştir. Ancak bazı normal hücrelerde de benzer özellikler bulunmakta ve bu hücreler de kemoterapiyle doğrudan etkilenmektedir. Bu etkilenmeler yan etkileri de doğurmaktadır. Bu nedenle yan etkiler daha çok kan hücreleri,
KURUM

1Fırat Üniversitesi, Veteriner Fakültesi, Dölerme ve Suni Tohumlama Anabilim Dalı, Elazığ, Türkiye

İETiŞiM

Gaffari Türk

E-posta:

gturk@firat.edu.tr

Gönderilme:

17.12.2012

Revizyon:

1.01.2013

Kabul:

16.01.2013 
gastrointestinal sistemdeki hücreler, k1l follikülleri ve spermler gibi hızlı bölünebilen hücreler üzerinden olmaktadır. Bunun d1şında bazı kemoterapötikler kalp, böbrekler, mesane, akciğerler ve sinir sistemi organları gibi hayati organlar üzerinde de olumsuz etkiler oluşturabilmektedir (4-7).

TABLO 1. Kimyasal yapılarına göre kemoterapötik ajanların sınıflandırılması [van der Kaaij ve ark. (101)'nın çalışmasından uyarlanmıştır]

\begin{tabular}{llc} 
Grup & İlaç ismi & $\begin{array}{c}\text { Hücre siklusuna } \\
\text { bağımlılığı? }\end{array}$ \\
\cline { 2 - 3 } $\begin{array}{ll}\text { Antimetabolitler } \\
\text { Folat antagonistleri }\end{array}$ & Metotreksat & Evet \\
Pirimidin analogları & 5-Fluorourasil, Gemsitabin, & Evet \\
& $\begin{array}{l}\text { Sitarabin } \\
\text { Pürin analogları }\end{array}$ & Azasitidin, Azatiyoprin, \\
& $\begin{array}{l}\text { Fludarabin, Kladribin, } \\
\text { 6-Merkaptopürin, Tiyoguanin }\end{array}$ & \\
& &
\end{tabular}

\begin{tabular}{|c|c|c|}
\hline \multicolumn{3}{|c|}{ Sitotoksik antibiyotikler } \\
\hline Antrasiklinler & $\begin{array}{l}\text { Daunorubisin, Doksorubisin, } \\
\text { Epirubisin, İdarubisin, } \\
\text { Plikamisin }\end{array}$ & Hayır \\
\hline Diğerleri & $\begin{array}{l}\text { Daktinomisin, Mitomisin } \\
\text { Bleomisin }\end{array}$ & $\begin{array}{l}\text { Hayır } \\
\text { Evet }\end{array}$ \\
\hline
\end{tabular}

$\begin{array}{lll}\begin{array}{l}\text { Alkilleyiciler ve benzer } \\ \text { etki gösterenler } \\ \text { Nitrojen mustardlar }\end{array} & \begin{array}{l}\text { Ifosfamid, Klorambusil, } \\ \text { Melfalan, Mekloretamin, } \\ \text { Siklofosfamid }\end{array} & \text { Hayır } \\ \text { Nitrozüreler } & \text { Karmustin, Lomustin } & \text { Hayır } \\ \text { Platin bileşikleri } & \text { Karboplatin, Sisplatin } & \text { Hayır } \\ \text { Diğerleri } & \text { Busulfan, Dakarbazin, } & \text { Hayır } \\ & \text { Prokarbazin } & \end{array}$

$\begin{array}{clc}\begin{array}{c}\text { Mikrotubül inhibitörleri } \\ \text { Vinka alkaloidleri }\end{array} & \begin{array}{l}\text { Vinblastin, Vindesin, } \\ \text { Vinkristin, Vinorelbin } \\ \text { Diğerleri }\end{array} & \text { Evet } \\ \text { Diğer kemoteraksel, Paklitaksel } & \text { Evet } \\ & \begin{array}{l}\text { Anti-androjenler, Anti- } \\ \text { Östrojenler, Glukokortikoidler, } \\ \text { Östrojenler } \\ \text { Imatinib, Sitokinler }\end{array} & \text { Evet } \\ & \begin{array}{l}\text { Etoposid, Teniposid, } \\ \text { L-asparajinaz }\end{array} & \text { Hayır }\end{array}$

İnfertilite evli çiftlerin \%15'ini etkileyebilmektedir. Bu oranın yarısını ise erkeğe bağlı infertilite oluşturmaktadır (8). Erkek faktörlü infertilite 1-4 hafta aralıklarla alınan iki ejakülattan en az birinde sperm motilitesi, sayısı ve morfolojisi gibi parametrelerden birindeki değişiklik olarak tanımlanmaktadır (9). Öte yandan kemoterapi alan evli çiftlerde ise uygulama bittikten sonra görülen infertilite oranı \%15-30'lara kadar çıkmaktadır (10-12). Kemoterapötikler kanserli olmayan normal doku ve hücrelerde de çeşitli düzeylerde yan etkilere sahip olduğu için erkek infertilitesi hatta sterilitesi kemoterapötik ilaçların üreme sisteminde meydana getirdiği olumsuz faktörlerden biridir $(5,7,12)$. Spermatogenesisteki aksakl1klar, sperm kalite parametrelerindeki bozukluklar, ejakülasyon bozukluğu, hipotalamus-hipofiz-gonad eksenindeki fonksiyon bozukluğu, cinsel işlev bozukluğu gibi olumsuz durumlar kemoterapötiklerin üreme sisteminde meydana getirdiği yan etkiler arasında gösterilmektedir $(6,7,12-17)$. Testisteki Leydig ve Sertoli hücreleri kısmen kemoterapötiklere dirençli iken, germinal epitelyum bu ilaçlara son derece duyarlıdır. Ancak kullanılan kemoterapi protokolünün ilaç sayısı, dozları ve uygulama sürelerine bağlı olmakla birlikte, eğer germinal epitelyumdaki kök hücreler sağlam kalırsa, tedavinin sonlandırılmasından sonra belli zaman periyodunda spermatogenesis geriye dönebilmektedir $(5,7,12,18)$.

Kanserli insan ve hayvanlarda yapılan pek çok çalışmada hormon uygulamalarının $(7,12,14)$, sperm $(7,12,19)$ ve testiküler doku kriyoprezervasyonunun (7), testiküler biyopsi aracılığıyla in vitro spermatogenesisin $(7,12)$, testis transplantasyonunun (7) ve çeşitli antioksidan maddeleri (20) ihtiva eden tamamlayıcı ve alternatif uygulamaların kemoterapiden önce ya da kemoterapi esnasında ilaçların erkek üreme sistemindeki yan etkilerinin azaltılması veya önlenmesinde etkili olduğu belirtilmektedir. Öte yandan farklı yapıdaki kemoterapötiklerin sağlıklı erkeklerin üreme sistemindeki yan etkilerini tespit etmek ve bu olumsuz etkilere karşı koruyucu önlemler almak amacıyla sayısız in vivo ve in vitro çalışma yapılmış ve halen de yapılmaktadır. Bu çalışmaların pek çoğunda kemoterapötiklerin genellikle oksidatif stresle ilişkili veya ilişkisiz DNA hasarı oluşturma mekanizmasıyla erkek üreme sisteminde yan etkilere sebep olduğu, dolayısıyla da farklı yapıdaki birçok antioksidan maddenin koruyucu rollere sahip olduğu bildirilmektedir (21-27). Bu derlemede de kanser tedavisinde yaygın olarak kullanılan kemoterapötiklerin kanserli ve sağlıklı erkeklerin üreme organ, doku ve hücrelerinde meydana getirdiği muhtemel yan etkiler ve bu etkilerin azaltılması veya önlenmesine yönelik koruyucu stratejiler ile ilgili literatür bilgiler sunulmaktadir.

\section{KEMOTERAPÖTIKLERIN ERKEK ÜREME SISTEMI ÜZERINDEKI YAN ETKI MEKANIZMASI}

Testisteki spermatogenik hücrelerin yüksek mitotik aktiviteye sahip olmaları ve kemoterapötik ajanların da daha çok hızlı proliferasyon gösteren hücrelerde toksik yan etki göstermelerinden dolayı, bu ajanların reprodüktif sistem üzerindeki etkilerini anlayabilmek için öncelikle spermatogenesisin farklı aşamalarının ve bu aşamalarda şekillenen hücre tiplerinin normal fizyolojik yapılarının iyi bilinmesi gereklidir. Spermatogenesis köken spermatogoniadan yaklaşık saniyede 1000 olgun spermatozoanin meydana geldiği (28), spermatositogenesis, meyosis ve spermiyogenesis aşamalarından ibaret birtakım hücre bölünmeleri ve farklılaşmalarını içeren aktif ve sürekli yenilenebilir bir süreçtir (Şekil 1). Spermatositogenesis sonucu spermatogoniadan spermatositler; meyosis sonucu spermatositlerden spermatidler ve spermiyogenesis sonucu da spermatidlerden olgun spermler şekillenmektedir (29). Öte yandan gelişim düzenine göre spermatogonia; köken, proliferatif (çoğalabilen) ve farklılaşan hücreler olmak üzere 3 sınıfa da ayrılabilmektedir. Kemoterapötiklerin erkek üreme sistemi üzerindeki yan etki mekanizması kesin olarak bilinmemekle birlikte spermatogenik hücrelerde doğrudan $(17,30,31)$ ve/ veya oksidatif stresle ilişkili olarak dolaylı $(20,32,33)$ meydana gelen kromatin ve DNA hasarı ile steroidogenesisteki aksaklıklar genellikle sorumlu tutulmaktadir. 


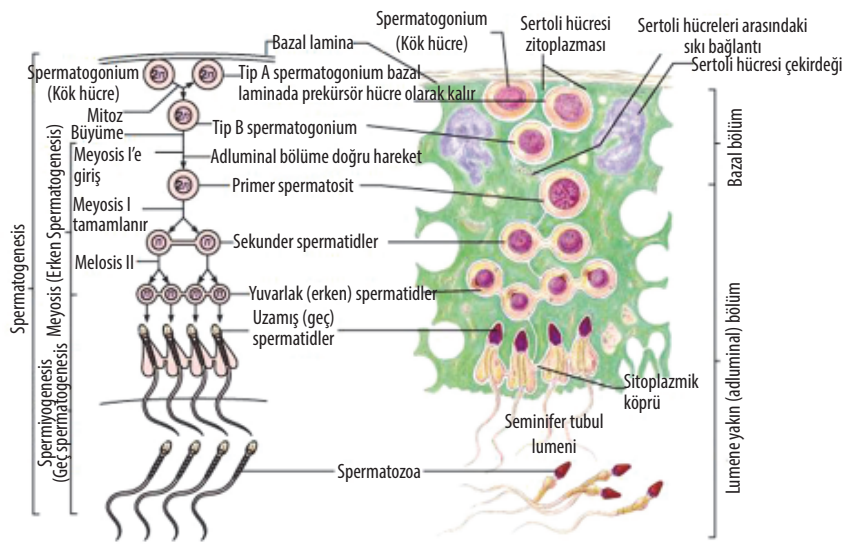

ŞEKiL 1. Spermatogenesisin aşamaları ve hücre tipleri [Meistrich (16)'dan uyarlanmıştr]

\section{Kemoterapötiklerin doğrudan yan etki mekanizması}

Kemoterapötikler hızlı proliferasyon ve farklılaşma yeteneğindeki sağllklı hücreler üzerinde primer yan etkiye sahip olduklarından dolayı sitotoksik kemoterapi doğrudan gonadal hasara neden olmakta ve bu hasarın derecesi de ilacın veriliş şekline, dozuna ve hastanın yaşına bağlı olarak değişebilmektedir. Kemoterapiye radyoterapi de eklendiğinde, düşük dozlarda bile spermatogenesis çok ciddi oranlarda etkilenmektedir. Köken spermatogoniumlar çoğalma ve farklılaşma göstermediklerinden dolayı proliferatif ve farklılaşan hücrelere göre kemoterapinin doğrudan etkilerine karşı genellikle daha dirençlidirler. Ancak proliferasyon ve farklılaşma gösteren spermatogoniumlar, spermatositler ve spermatidler ise kemoterapinin doğrudan etkilerine çok daha hassas olduklarından kemoterapötiklerle tedaviye başladıktan yaklaşık 4-6 hafta sonra fertilite potansiyeli düşmektedir (Şekil 2) (7,14). Sperm DNA'sı normal somatik hücre DNA'sına göre daha sıkı (condense) bir yapıya (34) sahip olmasına rağmen yine de pek çok olumsuz faktörden doğrudan ve/veya dolaylı olarak etkilenebilmektedir (32). Kemoterapötik ajanlar proliferatif ve özellikle de farklılaşma safhasına geçmiş spermatogenik hücrelerin DNA metilasyon profili (17), kromatin yapısı, spermlerin baş kısmmndaki basit (30) ve çekirdek matriks proteinleri (31) ile protamin ve histonların yapılarında olumsuz değişiklikler (35), spermatozoal dekondensasyon süresinde aksamalar (36), kromozomlarda anöploidiler (19) ve iğ ipliklerinde kırılmalar (35) gibi doğrudan DNA ve kromatin hasarları oluşturarak erkek üreme sisteminde yan etkiler meydana getirmektedirler.

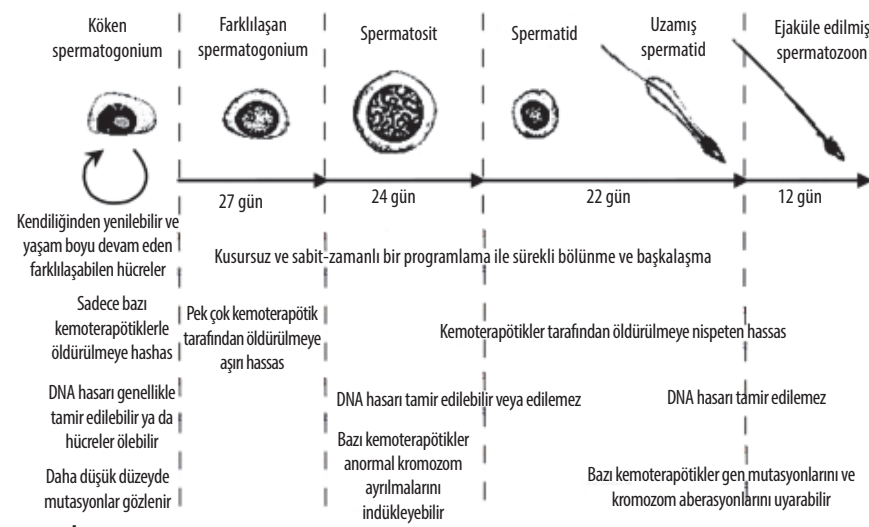

ŞEKiL 2. Kemoterapötik ajanların insanlardaki farklı spermatogenik hücreler ve ejaküle edilmiş spermatozoa üzerindeki etkilerinin şematik gösterimi [Meistrich (16)'in çalışmasından uyarlanmıştır].

\section{Kemoterapötiklerin oksidatif stresle ilişkili dolaylı yan etki mekanizması}

Oksijen canlılar için hayati önem taşıyan bir molekül olup hücrede enerji üretim süreçlerinde kullanılmaktadır. Normal metabolizma esnasında kullanılan oksijen serbest oksijen radikalleri üretiminde de artışa neden olabilmektedir. Serbest oksijen radikalleri bir veya daha fazla eşleşmemiş elektron içeren ve biyomoleküllerle karşılaştıklarında onların yapısını oksidatif olarak değiştirebilme kapasitesine sahip yüksek derecede reaktif moleküllerin bir grubudur. Bu radikaller; singlet oksijen $\left({ }^{1} \mathrm{O}_{2}\right)$, süperoksit radikali $\left(\mathrm{O}_{2}^{-\bullet}\right)$, hidroksil radikali $\left(\mathrm{OH}^{\bullet}\right)$ ve hidrojen peroksit $\left(\mathrm{H}_{2} \mathrm{O}_{2}\right)$ gibi reaktif oksijen türleri (ROS) ile nitrik oksit $\left(\mathrm{NO}{ }^{\bullet}\right)$ ve nitrojen dioksit $\left(\mathrm{NO}_{2}{ }^{\circ}\right)$ gibi reaktif nitrojen türlerinden oluşmaktadır (37). Organizmanın bütün hücre, doku, organ ve sistemlerinde serbest radikallerin oluşum hızı ile bunların enzimatik [Glutatyon-peroksidaz (GSH-Px), süperoksit dismutaz (SOD), katalaz] ve enzimatik olmayan [Glutatyon (GSH), vitamin A, E, C ve selenyum gibi] antioksidanlar tarafından ortadan kaldırılma hızı bir denge içerisindedir ve bu durum "oksidatif denge" olarak adlandirılır (28). Oksidatif denge sağlandığı sürece, serbest radikaller sağlıklı organizmayı etkilemediği gibi aksine pek çok fizyolojik olayın da düzenlenmesinde rol almaktadırlar. Örneğin; denge halindeki ROS düzeyleri sperm cAMP konsantrasyonu ve proteintirozin fosforilasyonunu arttırarak (38) spermlerin olgunlaşması, kapasitasyonu, akrozom reaksiyonu, hiperaktivasyonu ve sperm-oosit füzyonu gibi olayların düzenlenmesinde görev almaktadırlar (38-40). Bu radikallerin oluşum hızında artma ya da ortadan kaldırılma hızındaki bir düşme "oksidatif stres" $\mathrm{e}$ yol açmaktadır (28). Kemoterapiyi de içerisine alan birçok durum erkek infertilitesinin etiyolojisindeki en önemli faktörlerden biri olan oksidatif strese neden olmaktadır (Şekil 3) (20).

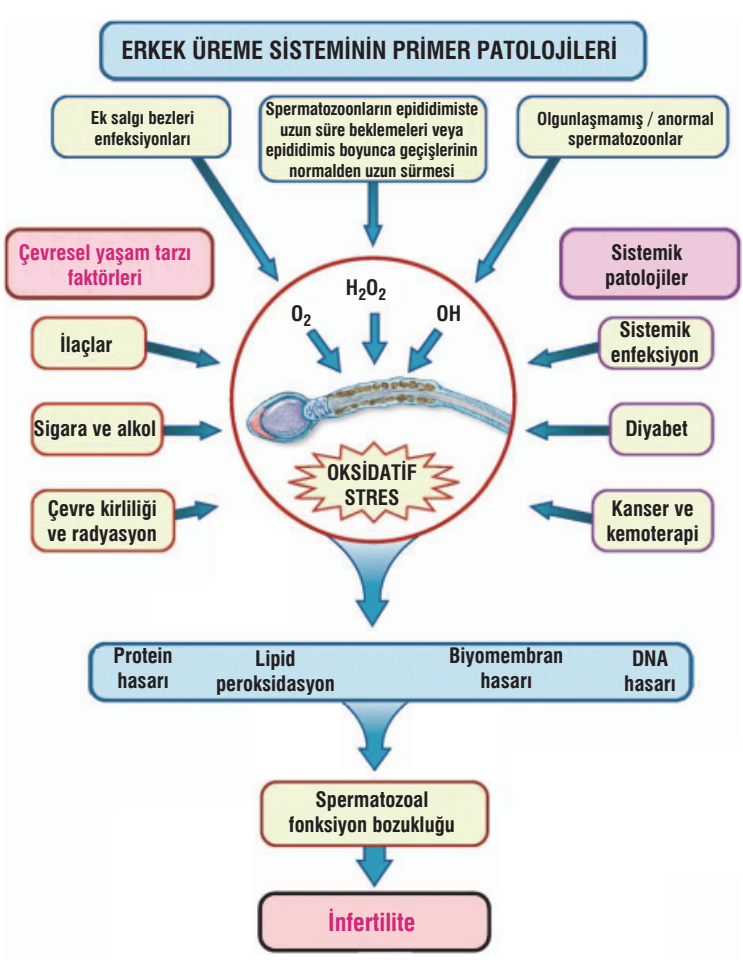

ŞEKiL 3. İnfertilite açısından büyük öneme sahip faktörlerden biri olan oksidatif strese yol açan erkek üreme sisteminin primer patolojileri [Agarwal ve Sekhon (20)'un çalışmasından uyarlanmıştır]. 
Serbest radikaller hücrelerde özellikle yağ asitleri ve lipidler olmak üzere proteinlere de saldırarak çeşitli yapı ve biyomembran bozukluklarına sebep olmaktadır. Memeli spermatozoonunun lipid kompozisyonu somatik hücrelerden önemli derecede farklıdır. Sperm plazma membranı fosfolipidler, steroller, doymuş ve doymamış yağ asitlerinden oldukça zengin olduğu için ROS hasarlarına karşı aşırı hassastırlar $(28,33,37,39,40)$. Kemoterapötikler de lipid, kolesterol ve protein peroksidasyonu ile oksidatif strese yol açarak özellikle spermatogenik hücrelerde DNA hasarı, apoptosis, sperm kalitesinde düşüşler, infertilite ve hatta sterilite gibi yan etkilerin erkek üreme sisteminde meydana gelmesine neden olmaktadirlar (21-23,26,41-43).

\section{KEMOTERAPÖTIKLERIN ERKEK ÜREME SISTEMI ÜZERINDEKI YAN ETKILERi Antimetabolitler}

Pürin veya pirimidin prekürsörlerinin sentezlerini bloke ederek ve DNA metilasyonunu önleyerek DNA ya da RNA sentezini inhibe ederler. Maksimal sitotoksik etkilerini hücre siklusunun S fazında gösterirler. Azasitidin, azatiyoprin, 5-fluorourasil, fludarabin, gemsitabin, kladribin, 6-merkaptopürin, metotreksat ve sitarabin bu grupta yer alan bazı ajanlardır (4).

\section{Kanserli erkeklerdeki etkileri}

Azatiyoprin kanser tedavisi yanında yangısal hastalıkların tedavisinde de kullanılan bir kemoterapötiktir. Azatiyoprinin yangısal bağırsak hastalığı (Inflammatory Bowel Disease) olan erkeklerde ejakülat miktarı, sperm motilitesi, yoğunluğu, anormal sperm oranı ve toplam sperm sayısı gibi spermatolojik parametreler üzerinde herhangi bir olumsuz etkiye sahip olmad1ğ bildirilmektedir (44). 5-fluorourasil doza bağlı olarak malignant lenfoma ve testiküler germ hücre tümörlü hastalarda spermatogenesiste yavaşlamaya bağlı olarak geçici azoospermi $(45,46)$ ve ayrıca oligospermi $(47)$ oluşturmaktadır. Kronik lenfositik löykemili hastalarda fludarabin uygulamasından sonra testis ağırlı̆̆ı ve testosteron düzeyinde azalma, oligospermi, sperm DNA hasarı ile FSH ve LH düzeylerinde artış gözlenmektedir (48). Taksanlarla kombine uygulanan gemsitabin kanserli hastalarda bilateral testiküler ağırlık azalması, ayrıca inhibin B düzeyinin azalması ve FSH düzeyinin artması gibi önemli gonadal lezyonlara neden olmaktadır (49). 6-merkaptopurinin infertilite riskinin düşük olduğu ve sadece geçici bir azoospermiye neden olduğu $(15,16)$ bildirilmesine rağmen Norgard ve ark. (50) 6-merkaptopurin veya azatiyoprin kullanan babalar ile sağlıklı annelerden doğacak çocuklarda kongenital anomali riskinin artacağını iddia etmektedirler. Osteosarkomlu erkeklerde postoperatif yüksek doz metotreksat uygulaması boyunca ve uygulamadan kısa bir süre sonrasına kadar hastaların yarısında oligospermi, azoospermi ve gonadotropin düzeylerinde artışların şekillendiği bildirilmesine rağmen (51) psoriasis tedavisinde de kullanılan bu ilacın 1-9 yıllık tedavi süresi boyunca sperm parametreleri üzerine herhangi bir olumsuz etkisinin olmadığ gözlenmiştir (52). Öte yandan French ve ark. (53)'nın yazmış olduğu derlemede de metotreksatın bazı araştırmacılar tarafından erkek fertilitesi üzerinde etkisiz kaldığı, bazıları tarafından da geçici steriliteye neden olduğu gibi zıt bilgiler sunulmaktadır. Sitarabinin erkek fertilitesi üzerinde zayıf bir etkisinin olduğu ileri sürülmesine rağmen $(47,54)$ çocukluk döneminde kanserli olan hastalarda ileriki yaşlarda sitarabin kullanımına bağlı olarak azoospermi ve şiddetli oligospermi oluştuğu da bildirilmiştir $(7,55)$.

\section{Sağlıklı erkek deney hayvanlarındaki etkileri}

Azasitidin siçanlarda spermatogenesisi olumsuz etkileyerek testisteki spermatid ve epididimisteki sperm sayısında azalmaya neden olmaktadır (56). Azatiyoprin sıçanların testis ağırlığında azalmalara, düzensiz ve atrofik seminifer tubüller ile vakuollü Sertoli hücrelerin oluşmasına (57), farelerde ise sperm sayısında azalmalara ve anormal spermlerde artışlara sebebiyet vermektedir (58). 5-fluorourasil uygulaması sıçanların testislerinde doza ve zamana bağlı olarak tubuler atrofiye (59), epididimal sperm sayısı (60) ve serum testosteron düzeylerinde (61) azalmaya yol açmaktadır. Gemsitabinin $10 \mathrm{mg} / \mathrm{kg}^{\prime}$ lık günlük dozu fare spermlerinde ciddi oranlarda morfolojik baş anomalilerine sebep olmaktadır (62). Bazı bilim adamları 6-merkaptopürinin farelerin premeyotik ve meyotik dönemdeki spermatogenik hücreleri üzerinde dominant letal etkiye sahip olduğunu bildirmelerine rağmen $(63,64)$ bazı araştırmacılar da gerçekte kronik merkaptopürin uygulamalarının laboratuvar hayvanlarında gerek sperm üretimi gerekse sperm morfolojisi üzerine herhangi bir etkisinin olmadığını $(65,66)$ veya en düşük gonadal toksisite oluşturduğunu (67) öne sürmektedirler. Antimetabolitlerin gonadal toksisitesi açısından laboratuvar hayvanlarında en fazla çalışılan ilaç metotreksattır (Şekil 4). Düşük ve orta doz metotreksatın sıçanlarda oligospermi oluşturduğu, ancak testiküler atrofiye neden olmadığı bildirilmiştir (68). Öte yandan sıçan testisleri üzerinde metotreksatla yapılan çalışmalarda testis ağırlığı, seminifer tubül çapı ve germinal epitel kalınlığında azalmalarla (69) birlikte dejenerasyonların şekillendiği (70), tüm spermatogenik hücreler olmak üzere özellikle spermatosit ve spermatidlerde öldürücü (71), Sertoli ve Leydig hücrelerinin büyüklüklerinde de azaltıcı (72) etkilere sahip olduğu tespit edilmiştir. Ayrıca farelerdeki sitogenetik çalışmaların sonuçları metotreksatın germ hücrelerinde çeşitli düzeylerde kromozamal aberasyonlar, DNA hasarı ve apoptosis oluşturduğunu, epididimal sperm sayısı ve motilitesinde azalmalara ve anormal sperm oranlarında da artışlara neden olduğunu göstermektedir $(25,43,73,74)$.
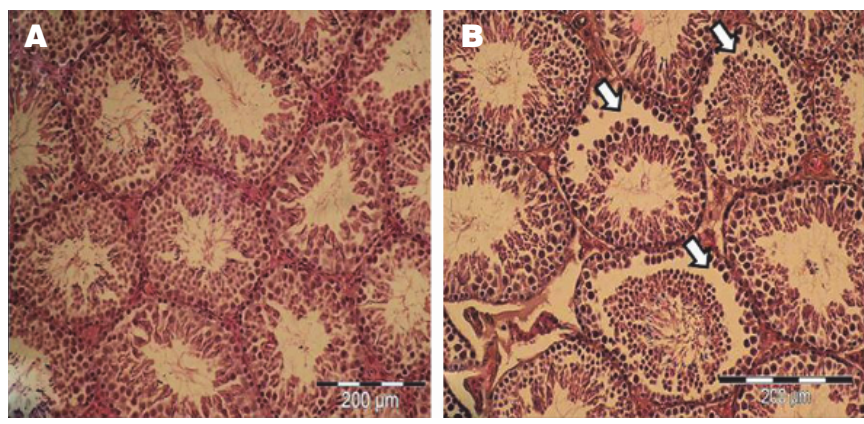

SEKiL 4. Kontrol grubu (A) farelere göre metotreksat uygulanan (B) hayvanların seminifer tubullerindeki şiddetli vakualizasyonun fotografik götüntüsü (oklar) [Padmanabhan ve ark. (25)'nın çalışmasından alıntılanmıştır].

\section{Antikanser antibiyotikler}

Antrasiklin antibiyotikler (daunorubisin, doksorubisin, epirubisin, idarubisin, plikamisin v.b.) iki DNA zinciri arasına yerleşerek DNA ve RNA sentezini inhibe ederler, topoizomeraz II enzimi üzerinden de DNA zincir kırılmalarına sebep olurlar. Ayrıca hücre membranlarına bağlanarak yapılarını ve iyonlara karşı geçirgenliğini değiştirirler. Bleomisin hücre siklusunun $\mathrm{G}_{2}$ fazında daha çok etkili olup oksidatif süreçle DNA k1rılmalarına sebep olmaktadır. Daktinomisin stabil bir daktinomisin-DNA kompleksi oluşturarak DNA'ya bağlı RNA polimerazın etkisini engellemektedir (75). 


\section{Kanserli erkeklerdeki etkileri}

Kanserli erkeklerin bu gruptaki ilaçlarla tek başlarına tedavilerinden sonra genellikle sperm sayısında geçici bir azalma ve fertilitelerinde düşük/orta şiddette azalmalar görülmesine rağmen kombine tedavilerden sonra daha şiddetli etkiler ortaya çıkabilmektedir $(15,16)$. Lemez $(76)$ yapmış olduğu bir çalışmada orta yaşlı akut myeloid löykemili 5 erkeğin daunorubisin tabanlı kombine tedavisinden sonra farklı bireylerde ereksiyon bozukluğu, ejakülat miktarında azalma ve şiddetli oligoastenoazoosperminin şekillendiğini bildirmektedir. Testiküler kanserli ya da Hodgkin lenfomalı erkeklerin doksorubisin tabanlı kombine tedavilerinden sonra \%38-40'1nda azoospermi ve şiddetli oligospermi şekillenmektedir (35). Bleomisinle birlikte farklı kemoterapötiklerin ortak kullanılması sonucu kanserli hastalarda oligo- ve azoo-spermi, spermlerde DNA hasarı (77) ile birlikte kromozomal anöploidiler (78) görülmektedir. Daktinomisinle kombine tedaviden sonra spermatogenesiste yavaşlama ve azoospermi şekillenmektedir (46).

\section{Sağlıklı erkek deney hayvanlarındaki etkileri}

Farklı doz daunorubisin uygulamaları farelerin germ hücrelerinde kromozomal aberasyonlara ve spermlerde morfolojik bozukluklara neden olmaktadır (79). Doksorubisin sağlıklı erkeklerde antikanser antibiyotiklerin erkek üreme sistemi üzerindeki etkilerinin gösterilmesi açısından en fazla çalışmanın yapıldığ1 kemoterapötiktir (Şekil 5). Doksorubisin sıçanlarda testis, epididimis, seminal bez, prostat ağırlıkları ile sperm sayısı, motilitesi, testosteron düzeylerinde önemli azalmalara, sperm anormalitesinde önemli artışlara, seminifer tubul çapları ve germinal hücre tabakası kalınlığında azalma, bozulmuş spermatogenesis, dejenerasyon, ödem ve nekroz gibi ciddi testiküler histopatolojik lezyonlara $(23,80,81)$, spermlerde DNA hasarı (82) ile spermatogenik hücrelerde Bax, Bcl-2, p53, Fas ve kaspaz indikatörlü apoptosise (83-85) neden olmaktadır. Ayrıca sıçanların testis dokusunda yer alan ve sperm plazma membranının yapısına iştirak eden hem uzun $\left(\mathrm{C}_{18}{ }^{-} \mathrm{C}_{22}\right)$ hem de çok uzun $\left(\mathrm{C}_{24}-\mathrm{C}_{32}\right)$ zincirli doymamış yağ asidi düzeylerinde önemli değişikliklere neden olduğu da bildirilmektedir (86). Doksorubisinin farelerde de normal sperm morfolojisi, günlük sperm üretimi ve Sertoli hücre sayısında önemli azalmalara, Sertoli ve germ hücreleri ile ilişkili genlerin mRNA düzeylerinde regülasyon bozukluğuna (87), testis ağırlığında azalma, seminifer tubul çaplarında daralma, spermatogenesiste hasar gibi histopatolojik lezyonlara (88), testiküler DNA hasarı (89), spermatogoniumlarda kromozomal aberasyonlar (90) ve apoptosise (91) neden olduğu bildirilirken öte yandan spermatogenesisteki hücrelerin telomeraz aktivitesi üzerine de etkisinin olmadığı öne sürülmektedir (88). On hafta boyunca haftada bir kez 1,2 $\mathrm{mg} / \mathrm{kg}$ epirubisin uygulaması sıçanlarda germ hücre apoptosisine neden olmaktadır (92). Arrebola ve ark. (93) ise bir diğer antikanser antibiyotik olan bleomisini, günlük $30 \mathrm{mg} / \mathrm{kg}$ dozunda 5 gün boyunca intraperitoneal olarak sıçanlara uygulamışlar ve 52 gün sonra bu hayvanları dekapite ettiklerinde sperm sayısında azalma ve anormal sperm oranında da artışlar tespit etmişlerdir. Benzer şekilde Hansen ve Sorensen (94) 100 $\mathrm{mg} / \mathrm{kg}$ bleomisinin farklılaşma sürecindeki fare spermatogoniumlarının yaşama oranını \%37'den \% $4^{\prime}$ lere düşürdüğünü gözlemlemişlerdir. Öte yandan puberte öncesi dönemde daktinomisin uygulanan sıçanlarda puberteden sonra testis histolojisinde yapisal bozukluklarla spermatogenik hücrelerde apoptosisin şekillendiği bildirilmektedir (95).

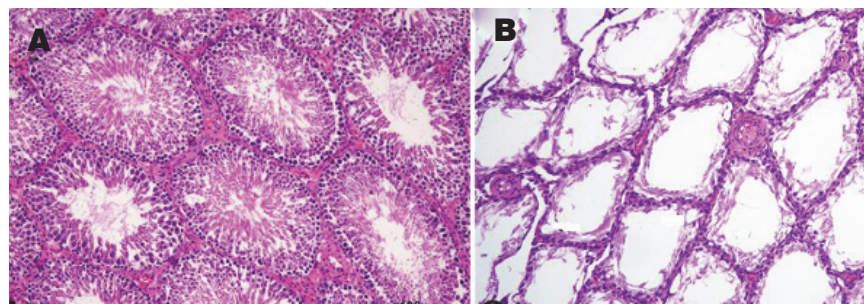

ŞEKiL 5. Doksorubisin uygulanmayan (A) ve uygulanan (B) sıçanlarda testislerin histopatolojik görüntüsü [Çeribaşı ve ark. (85)'nın çalışmasından alıntılanmıştır]

\section{Alkilleyiciler ve benzer etki gösterenler}

Dinlenen veya bölünen hüceleri ayırmayan (hücre siklusundan bağımsız) alkillleyiciler sitotoksik etkilerini çeşitli hücre yapılarındaki nükleofilik gruplara kovalent bağlanarak gösterirler. Adeninin 1 ve 3, guaninin 7 ve sitozinin 1 numaralı azot atomları DNA'nın alkillenmesinde en önemli hedeflerdir. Bu atomların alkillenmesiyle zincir-içi veya zincirler-arası çapraz bağlar oluşur ve böylece sadece DNA transkripsiyonu değil çoğalması da etkilenmiş olur. İfosfamid, klorambusil, melfalan, mekloretamin, siklofosfamid gibi nitrojen mustardlar; karmustin, lomustin gibi nitrozüreler; karboplatin, sisplatin gibi platin bileşikleri ile busulfan, dakarbazin ve prokarbazin bu grupta yer alan ilaçlardır (96).

\section{Kanserli erkeklerdeki etkileri}

Kemoterapötik ilaçlar içerisinde kanserli veya farklı hastalıklara sahip erkeklerde en fazla gonadal yan etkiye sahip ilaç grubu alkilleyici ajanlardır $(15,16)$. Bu gruptaki hemen hemen her bir ilaç uzun süre devam eden azoospermiye neden olduğundan tedaviden sonraki infertilite riski oldukça yüksektir $(5,15)$. Örneğin, klorambusil ile 14 yil tedavi edilen bir hastada kemoterapiden sonraki 15 y1l boyunca azoosperminin devam ettiği, dolayısıyla spermatogenesisin çok uzun süre sonra normale dönebildiği bildirilmektedir (97). Öte yandan nefrotik sendromlu prepubertal ve pubertal dönemdeki erkeklerin klorambusil ile tedavisinden sonra hastaların pek çoğunda testiküler hipotrofi, serum FSH düzeyinde artış, azoospermi ve bir hastada da şiddetli oligospermi gözlendiği rapor edilmiştir $(98,99)$. Benzer şekilde Thomson ve ark. (55) çocukluk döneminde klorambusil ile kanser tedavisi gören hastalarda ileriki yaşlarda azoospermi ve oligosperminin şekillendiğini öne sürmektedirler. Williams ve ark. (100) yaptıkları bir çalışmada ifosfamid $\left(>60 \mathrm{~g} / \mathrm{m}^{2}\right)$ alan kanserli 32 hastanın 2/3'ünün sperma analizlerinde subfertilite (azoospermi), \%31'inin FSH düzeylerinde artış ve \%50'sinin de inhibin B düzeylerinde azalma ile karakterize germ hücre hasarının saptandığını ve ayrıca erkek hastaların ifosfamid gonadotoksisitesine karşı kadınlara göre çok daha hassas olduklarını iddia etmektedirler. Melfalan ile tedaviden sonra uzun süre devam eden azoospermi görülmektedir $(5,15)$. Siklofosfamid ve prokarbazin alkilleyiciler içerisinde gonadal toksisitesi en yüksek olan kemoterapötiklerdir (101). Germinal epitel üzerinde çok güçlü toksik etkiye sahip olan siklofosfamid prepubertal dönemde bu ilaçla tedavi gören çocukların yetişkinlik dönemlerindeki fertilite potansiyellerini \%50'lere kadar düşürebilmektedir (102). Benzer şekilde siklofosfamid ile kanser tedavisi gören çocuklarda tedavi sonrası 20 yıllık bir süre boyunca devam eden azoospermi $(103,104)$ ve hatta kalıcı sterilite şekillenmekte olup (105) bunun sebebinin de sperm rejenerasyonundaki başarısızlıklar olduğu iddia edilmektedir $(7,106)$. Prepubertal dönemde 1g/ $\mathrm{m}^{2}$ karmustin ve $500 \mathrm{mg} / \mathrm{m}^{2}$ lomustin ile tedavi edilen beyin 
tümörlü çocukların \%50'sinde yetişkinlik dönemlerinde azoospermi şekillendiği bildirilmiştir $(5,15,107)$. Reiter ve ark. (108) karboplatinle tedavi edilen testiküler seminomalı 22 hastanın sadece 7'sinde oligospermi, 14'ünde ise FSH düzeylerinde artış şekillendiğini, bununla birlikte azoospermi oluşmadığını ve hastaların iyileştikten sonraki fertilitelerini kazanma durumlarının yüksek olduğunu bildirmektedirler. Bir diğer alkilleyici ajan olan sisplatin testiküler kanserli hastaların tedavisinde en sık kullanılan ilaçtır. Bu ilacın kemoterapötik olarak kullanılmasıyla birlikte testiküler germ hücre tümörlü erkeklerin yaşam süresinde de artışlar meydana gelmiştir (46). Küratif etkisinin yanında gonadotoksik etkisinin de yüksek olması nedeniyle kemoterapötiklerin özellikle de alkilleyici ajanların kanserli ve sağlıklı erkeklerin reprodüktif sistemi üzerindeki etkileri ile ilgili pek çok çalışma sisplatinle yapılmiştır (12). Sadece sisplatin veya sisplatin tabanlı kombine kemoterapi alan kanserli hastaların hemen hemen hepsinde akut azoospermi şekillenmektedir (46). Hastaların yaklaşık yarısında kemoterapiden sonraki 6 ay ile 5 yıl arasındaki bir sürede sperm sayısında normalleşme görülmektedir (109). Bununla birlikte hastaların \%30'unda da kalıcı azoospermi meydana gelmektedir (11). Geriye dönüşümsüz spermatogenesis hasarı ise sisplatinin kümülatif dozu ile ilişkili olup $400 \mathrm{mg} / \mathrm{m}^{2}{ }^{\prime}$ den düşük dozlar uzun süre sperm üretimini baskılarken 600 mg/ $\mathrm{m}^{2}$ 'den daha yüksek dozlarda kalıcı azoospermi riski artmaktadır $(18,46)$. Sisplatin tabanlı kemoterapiden sonra testis tümörlü erkeklerin spermlerinde görülen kırık DNA artışlarına $(77,110)$ rağmen, yapılan sperm karyotip analizlerine göre bu hastalarda kromozom anomalileri açısından herhangi bir risk bulunmadığı ileri sürülmektedir (111). Bununla birlikte Gerl ve ark. (112) $400 \mathrm{mg} / \mathrm{m}^{2}$ den daha yüksek dozda 75 ay boyunca sisplatin alan germ hücre tümörlü erkeklerde almayanlara göre testosteron düzeylerinde önemli azalma, FSH ve LH düzeylerinde ise önemli artışlar tespit etmişler ve sisplatinle yüksek doz kemoterapinin testis kanserli erkeklerin Leydig hücrelerinde kalıcı fonksiyon bozukluğu oluşturduğu kanaatine varmışlardır. Azoospermi ve yüksek infertilite riski olduğu ileri sürülen alkilleyici busulfanın $(5,15) 600 \mathrm{mg} / \mathrm{m}^{2}$ 'lik dozu kemik iliği transplantasyonu yapılan erkeklerde spermatogenesisin baskılanmasına neden olmaktadır (113). Dakarbazin kemoterapisi hastalarda genellikle geçici bir azoospermi ile sonuçlanmaktadır (15). Siklofosfamid ve sisplatin gibi yüksek gonadotoksik etkiye sahip alkilleyici ajanlardan biri olan prokarbazin (101), lenfatik malignantlı erkeklerde $4 \mathrm{~g} / \mathrm{m}^{2}$ 'nin üstündeki dozlarda kullanıldığında spermatogenesiste meydana getirdiği çok ciddi hasarlara (18) bağlı olarak uzun süre devam eden azoospermi $(5,15,55)$ ve oligospermi ile yüksek infertilite riskine sahiptir $(7,55)$.

\section{Sağlıklı erkek deney hayvanlarındaki etkileri}

Spermatogenik hücreler üzerinde yüksek mutatik aktiviteye sahip olan klorambusil post-meyotik safhadaki ve özellikle de erken dönemdeki fare spermatidlerinde dominant letal mutasyon $(114,115)$ ve kalitsal translokasyonlara (114) neden olmaktadır. İfosfamidin farklı dozlarının tek enjeksiyonlarını müteakip doza bağlı olarak tavşanların testis ve ek salgı bezi ağırlıklarında geçici azalma, benzer şekilde spermatositogenesis (240 $\mathrm{mg} / \mathrm{kg})$ ve spermiogenesis $(60,90$ ve $120 \mathrm{mg} / \mathrm{kg})$ ile epididimisteki sperm olgunlaşması olaylarında geçici baskılanmalara bağlı olarak oligo-, teratozoo- ve asthenozoo-spermi şekillenmekte olup tedavi sonrası maksimum 8. haftada tekrar normale dönüşler meydana gelmektedir (116). Mutajenik etkili olan ifosfamid farelerde de doza bağımlı olarak testiküler germ hücrelerinde kromozomal aberasyonlara ve spermlerde morfolojik bozukluklara sebebiyet vermektedir $(41,117)$. Melfalan enjekte edilen farelerde spermatogenesisin son safhasındaki hücrelerde dominant letal mutasyonlar ve kalıtsal translokasyonlar gibi ciddi kromozomal anomaliler meydana gelmektedir (118). Ayrica melfalan in vitro olarak boğa spermasına katıldığında spermlerde DNA hasarlarına da neden olmaktadır (119). Mekloretamin fare spermatogoniumlarında dominant letal mutasyonlara neden olmaktadır (120). Siklofosfamidle yapılan deneysel sıçan çalışmalarında sperm konsantrasyonu ve motilitesinde azalma, apoptotik germ hücre sayısı, ölü ve anormal sperm oranında artma, şiddetli testiküler yapı bozuklukları $(26,121,122)$ testosteron $(121,123)$ A tipi spermatogoniumlar, preleptoten ve pahiten spermatositler ile spermatidlerde azalmalar (123) ve ayn zamanda sperm nüklear matriks profili (31), sperm kromozom yapısı ve basit proteinlerinde değişiklik (30) ile spermatosit DNA'sında çift zincir kırıkları (Şekil 6) da tespit edilmiştir $(124,125)$. Siklofosfamidin sıçanlarda oluşturduğu reprodüktif yan etkilerin pek çoğu farelerde de gözlenmektedir $(90,126-128)$.
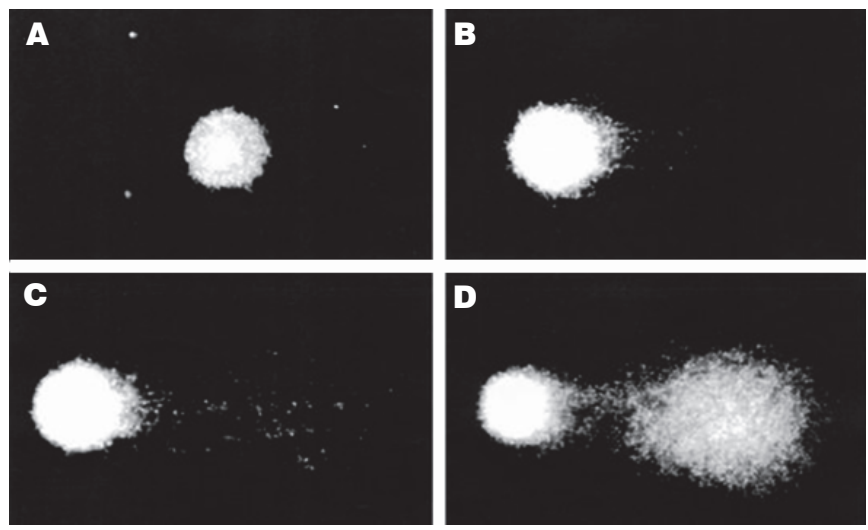

SEKiL 6. Siklofosfamid uygulanmayanlara göre (A) uygulanan sıçanlarda (B-D) sperm nükleusunda şekillenen DNA hasarının comet analiz yöntemiyle gösterimi [Codrington ve ark. (124)'nın çalışmasından alıntılanmıştır].

Nitrozürelerden karmustin ve lomustin fare spermatositlerindeki kromozomal hasarlarda önemli artışlara (67), postspermatogonial hücrelerde dominant letal ve spesifik lokus mutasyonlarına neden olmaktadırlar (129). Platin bileşiklerinden karboplatin uygulaması sonucunda sıçanlarda testiküler histopatolojik lezyonlar (spermatogenesiste yavaşlama; spermatogonium, spermatosit, spermatid, Leydig hücrelerinde azalma ve dejenerasyon), steroidogenik enzimlerin (3 $\beta$-hidroksisteroid dehidrogenaz, 17 $\beta$-hidroksisteroid dehidrogenaz) testiküler aktiviteleri ve serum testosteron düzeyinde azalmalar, serum FSH ve LH düzeylerinde artışlar (130), sperm sayısı ve motilitesinde azalmalar ile ayrica sperm membran bütünlüğünde bozulmalar (131) gibi önemli reprodüktif sistem hasarları meydana gelmektedir. Yetişkin erkek sıçanlarla yapılan pek çok çalışmada, sisplatinin testis, epididimis, seminal bez ve prostat ağırlıkları, sperm yoğunluğu, motilitesi ve morfolojik olarak normal yapılı spermlerin say1sında azalmalara, seminifer tubul çaplarında daralmalara, testiküler dokuda dejenerasyon, nekroz ve ödem gibi histopatolojik lezyonlara $(21,22,121,132-136)$, testiküler apoptotik germ hücre sayısı $(27,137)$, serum FSH düzeyinde artışlara (138), 
sperm DNA'sinda kırılmalara (139) ve testosteron düzeylerinde ise azalmalara $(121,135,140,141)$ yol açtığ bildirilmektedir. Pubertal dönemde sisplatin verilen sıçanlarda da benzer etkilerin görüldüğü bir çalışmada; Favareto ve ark. (142) 45 günlük pubertal dönemdeki sıçanlara $1 \mathrm{mg} / \mathrm{kg} /$ gün dozunda 3 hafta boyunca sisplatin uygulamasının hayvanlar 66 günlük olduklarında testiküler histopatolojik lezyonlar (Şekil 7) ile birlikte tüm reprodüktif organ ağırlıkları, sperm üretimi, yoğunluğu, motilitesi, seminifer tubul çapı, intratestiküler testosteron miktarı, fertilite potansiyeli ve libidoyu önemli derecede azalttığını, TUNEL-pozitif apoptotik hücrelerin ve motil olmayan spermlerin sayısını da önemli derecede artırdı̆̆ını gözlemlemişlerdir. Aynı çalışmada hayvanlar 140 günlük oldukları dönemdeki reprodüktif parametreleri de incelenmiş ve sperm motilitesi ile testiküler histopatolojik lezyonlar hariç diğer parametrelerde kendiliğinden iyileşmelerin gözlendiği tespit edilmiştir (142). Fareler üzerinde yapılan çalışmalarda da sisplatinin, sperm kalite parametreleri, testiküler histolojik yapı ve üreme organ ağırlıklarında olumsuz değişikliklere (143), spermlerde geri dönüşümsüz DNA çift zincir kırıkları (144) ve spermatogoniumlarda kromozomal aberasyonlar (90) gibi sıçanlardaki reprodüktif yan etkilere benzer toksisiteye neden olduğu tespit edilmiştir.
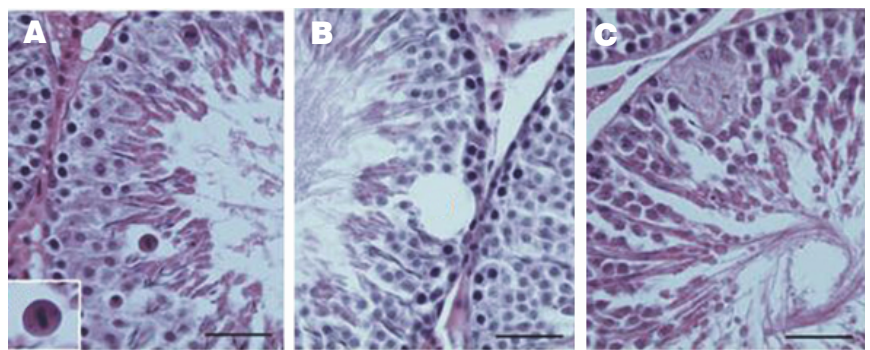

ŞEKiL 7. Sisplatin uygulanan sıçan testislerinde piknotik hücre oluşumu (A), Sertoli hücrelerinde vakualizasyon (B) ve germ hücre yokluğu (C) [Favareto ve ark. (142)'nın çalışmasından alıntılanmıştır].

Alkilleyici ajanlardan busulfan, farelerin testis ve epididimis ağırlıklarında azalmalar, seminifer tubullerinde atrofi (145147), testiküler spermatogenik hücreler, sperm sayısı, motilitesi ve yaşayabilirliği $(145,147)$ ile testosteron düzeylerinde önemli azalmalar, anormal sperm oranı ve apoptotik hücre sayısında artışlar (42), seminal bez sekresyonunda azalma ve bezin histolojik yapısında bozukluklar oluşturmasına rağmen (148), spermatogenik hücelerde kromozomal aberasyonlara neden olmamaktadır (149). Kumar ve ark. (150) dakarbazinin epididimal sperm sayısı, sperm motilitesi ve intratestiküler testosteron düzeylerinde önemli azalmalar, anormal yapılı spermlerin oranında da önemli artışlar oluşturduğunu bildirmektedirler. Prokarbazin uygulanan sıçanların testislerinde atrofi $(151,152)$, Setoli ve Leydig hücrelerindeki fonksiyon bozukluğuna bağlı olarak androjen bağlayıcı protein ile testosteron düzeylerinde azalma, FSH düzeylerinde artış, ayrıca spermatogenesisteki aksaklıklar (153-155) sonucu epididimal sperm rezervlerinde azalma ve infertilite $(154,155)$ gözlendiği bildirilmiştir. Prokarbazinle yapılan deneysel fare çalışmalarında sperm sayısında azalma (156), hamsterlerin anormal sperm sayısında artış, sperm konsantrasyonunda azalma ile birlikte sperm başının elektron mikroskobik görüntüsünde nükleus ve akrozomal membranda şiddetli hasarlar tespit edilmiştir (157).

\section{Mikrotubül inhibitörleri}

Çeşitli bitkisel kaynaklı maddeler mitoz esnasında sitoplazma içi hareketleri kontrol eden mikrotubüllerin arasındaki polimerize ve depolimerize yapıların dengesini bozarak sitotoksik etki oluşturmaktadır. Vinblastin, vindesin, vinkristin ve vinorelbin gibi vinka alkaloidleri tubuline bağlanarak polimerizasyonu inhibe eden bitkisel kaynaklı mikrotubül inhibitörü kemoterapötikleridir. Dosetaksel ve paklitaksel ise tubüllerin yapılmasını engellemeden depolimerize olmamalarını sağlayarak tubülleri stabil hale getirirler ve böylece onların fonksiyonlarını bozarlar (158).

\section{Kanserli erkeklerdeki etkileri}

Vinka alkaloidlerinin tek başlarına kullanıldıklarında geçici bir süre azoospermi oluşturmalarına istinaden genellikle infertilite riskleri düşüktür $(5,15,16)$. Çocukluk çağında vinblastin (103) ya da vinkristinle (55) tedavi edilen hastaların yetişkinlik dönemlerinde azoospermi ve şiddetli oligospermi şekillendiği bildirilmektedir. Öte yandan TVT (Transmissible Venereal Tumor)'li köpeklerin tedavisi amacıyla sıklıkla kullanılan vinkristin uygulaması esnasında libido ve testis hacmi etkilenmemesine (159) rağmen, sperma miktarı, sperm yoğunluğu, motilitesi, anormal sperm oranı ve sperm membran bütünlüğü gibi spermatolojik parametreler kötüleşmekte, fakat kemoterapiden 15 gün (160) veya 45 gün (159) sonra bu değerlerde normalleşme görülmektedir. Dosetaksel ve paklitaksel tabanlı kemoterapi uygulamasından sonraki kısa peryot boyunca kanserli hastalarda testiküler hacim ve serum inhibin B düzeyinde azalma ile serum FSH düzeyinde artış gibi aksaklıklar meydana gelmektedir (49).

\section{Sağlıklı erkek deney hayvanlarındaki etkileri}

Vinblastin fare spermatogoniumları ve primer spermatositlerinde kormozomal aberasyonlara (161), testiküler atrofi, sperm sayısında azalma, anormal sperm oranında artış, germ hücrelerde DNA tek zincir kırıkları ve fertilite düşüklügüne neden olmaktadır (162). Vinkristin sıçanlarda testiküler atrofi, spermatogenesis ve steroidogenesiste rolü olan Sertoli, Leydig ve germ hücrelerine ait çeşitli proteinlerin miktarlarında azalmalar (163), apoptotik germ hücre say1sında artışlar (95) oluşturmakta ve epididimal dokudaki hücrelere zarar vererek spermlerin olgunlaşmasını engellemektedir (164). Bu alkaloidler, farelerde de spermatosit ve spermatid DNA'sında hasara, germ hücre gelişim oranında azalmaya, spermatidlerde ölümlere (165), testiküler atrofi, sperm sayısında azalma ve anormal spermlerde artışlara (166) neden olmaktadır. Bir diğer mikrotubül inhibitörü olan paklitakselin gonadotoksik etkilerini araştıran KoehlerSamouilidou ve ark. (167) 4 hafta boyunca haftada bir kez $12,4 \mathrm{mg} / \mathrm{kg}$ paklitaksel uyguladıkları sıçanların yarısını uygulama bittikten 6 gün (kısa süre) diğer yarısını da 11 hafta (uzun süre) sonra dekapite ederek reprodüktif parametreleri incelemişlerdir. Sonuçta; kısa süre sonra dekapite edilen hayvanlarda prostat bezi, epididimis ve testis ağırlıkları ile sperm yoğunluğu ve motilitesinde azalmalar, testisin histolojik yapısı incelendiğinde ise Leydig hücrelerinde dejenerasyon, spermatogonium, spermatosit ve spermatidlerde de azalmalar olduğu tespit edilmiştir. Buna rağmen uzun süre sonra dekapite edilen hayvanlarda ise sperm yoğunluğundaki azalma hariç diğer parametrelerde önemli düzelmelerin şekillendiği gözlenmiştir. 


\section{Diğer kemoterapötikler}

Etoposid ve teniposid gibi podofilotoksinler $\mathrm{S}$ sonu- $\mathrm{G}_{2}$ fazı ile mitokondri fonksiyonlarını inhibe etmektedirler. Asparajini aspartik asit ve amonyağa parçalayan L-asparajinaz, akut lenfositik lösemi gibi egzojen asparajine ihtiyaç duyan tümör hücrelerine karşı etkindir. Hormonlara duyarlı veya bağımlı bazı tümörlerin tedavilerinde ise hormon agonist veya antagonistleri kullanılmaktadır. Glukokortikoidler lenfosit proliferasyonu üzerine negatif etkili oldukları için lösemi ve lenfomalarda daha çok prednizon kullanılır. Dietilstilbestrol gibi östrojenler de androjenlere duyarlı bazı prostat tümörlerinin tedavisinde etkilidir. Formestan gibi aromataz inhibitörleri ile flutamid ve siproteran asetat gibi androjen antagonistleri prostat tümörlerinde, tamoksifen gibi anti-östrojenler de bazı meme ve endometriyal kanserlerde kullanılmaktadırlar. Bir protein tirozin kinaz inhibitörü olan imatinib, kronik myeloid lösemili hastalarda olduğu gibi anormal tirozin kinaz aktivitesi tespit edilen kanserlerde Bcr-Abl tirozin kinazı inhibe ederek etkisini göstermektedir. İmmunostimulan etkili sitokinler özellikle interferonlar lösemi, AIDS ve hepatitli hastalarda makrofaj ve doğal öldürücü hücreleri stimüle etmek amacıyla kullanılır $(4,158)$.

\section{Kanserli erkeklerdeki etkileri}

Etoposidin tek başına kullanılmasının geçici bir azoospermiye ve düşük gonadal toksisiteye neden olduğu bildirilmekte $(5,15,16,101)$ olup kanserli hastalarda genellikle kombinasyon tarzında kullanılmaktadır. Etoposidle birlikte birkaç kemoterapötiğin kombinasyon tarzında testiküler tümörlü hastalarda kullanılması sonucunda kemoterapiyi müteakip spermatogenesis ve Leydig hücrelerinde fonksiyon bozukluğu (110) ile spermatozoonlarda artan derecede anöploidi (168) gibi reprodüktif yan etkiler meydana gelmektedir. Bu etkilerin ise etoposidden ziyade daha çok diğer ajanların etkisi ile ortaya çıtığı ileri sürülmektedir (168). Asparajinaz benzeri bir protein rat testislerinden izole edilmesine ve bu proteinin de spermler için otoantijen olarak kabul edilmesine rağmen (169) kemoterapi amaciyla kullanılan L-asparajinazın gerek kanserli gerekse sağlıklı erkeklerin spermatogenesisi, sperm kalite parametreleri, testiküler histolojik yapısı, reprodüktif hormonları, seksüel davranışları ve fertilitesi üzerine etkileri ile ilgili henüz yapılmış bir çalışma bulunmamaktadır. Hodgkin lenfomalı hastalarda prednizon tedavisi sperm üretimi ve kalitesi üzerine herhangi bir etkiye sahip değilken (170) günlük 10 mg'llk dozdan daha yüksek alınması sperm sayısında önemli azalmalar oluşturmaktadır (171). Ayrıca peripubertal dönemde transplantasyon geçiren erkeklerde de immunosupressif amaçla kullanıldığında spermlerde fonksiyonel bozukluklara neden olduğu bildirilmektedir (172). Dietilstilbestrol, aromataz inhibitörleri, anti-androjenler ve antiöstrojenlerin kanserli erkeklerin infertilitesi üzerine etkisi ile ilgili henüz yapılmış bir çalışma bulunmamaktadır. Bununla birlikte düşük testosteron/östradiol oranına sahip infertil erkeklerde aromataz inhibitörleri kullanımı bu oranda ve sperm kalite parametrelerinde iyileşmeler sağlamaktadır (173). Öte yandan sağlıklı insanlarda bir anti-androjen olan siproteron asetat kullanımı gonadotropin hormon seviyesini düşürerek, ciddi azoospermiye neden olmakta ve erkekler için kontraseptif olarak önerilmektedir (174). Öte yandan, hipereozinofilik sendromlu 18 yaşındaki bir hastada bir yıl boyunca imatinib kullanımindan sonra şiddetli oligoasthenoteratozoospermi (175), benzer şekilde kronik myeloid löykemili bir hastada da oligozoospermi ve inhibin B/FSH oranında azalma (176) vakaları bildirilmiştir. Schilsky ve ark. (177) löykemili 48 hastada interferon- $a 2$ ' nin testislerin fonksiyonu üzerine herhangi bir etkisinin olmadığını bildirmesine rağmen, Longo ve ark. (178) III. derece melanomlu bir hastada interferon- $\alpha$ alımına bağlı azoospermi vakasını tespit etmişlerdir. Benzer şekilde hepatit $C$ tedavisi için interferon alan erkeklerde motil sperm sayısında azalma ile birlikte spermlerde DNA hasarları şekillendiği bildirilmektedir (179). İnterferonlar ayrıca sağlıklı insanlarda spermadaki sodyum-potasyum-ATPaz, kalsiyum-ATPaz, süperoksit dismutaz ve nitrik oksiti etkileyerek spermlerdeki akrozin aktivitesi ile akrozom reaksiyonunu da inhibe edebilmektedirler (180).

\section{Sağlıklı erkek deney hayvanlarındaki etkileri}

Prepubertal dönemde sıçanlara uygulanan etoposid doza bağımlı olarak apoptotik germ hücre sayısında artış (Şekil 8) (181), reprodüktif organ ağırlıkları ile spermatogonium, spermatosit ve spermatidlerde azalma, testiküler histopatolojik lezyonlar ve infertiliteye (182) neden olmaktadır. Farelerde yapılan çalışmalarda da etoposidin farklılaşmakta olan spermatogoniumlar ve spermatositlerde kromozom kırıklarına (klastojenik etki) neden olduğu bildirilmektedir $(183,184)$. Etoposidin spermatogoniumlardaki klastojenik etkisinin 8 hafta sonra da olgun spermlere taşındığı, anormal sperm say1sındaki artışın da bu durumun göstergesi olduğu ileri sürülmektedir (183).

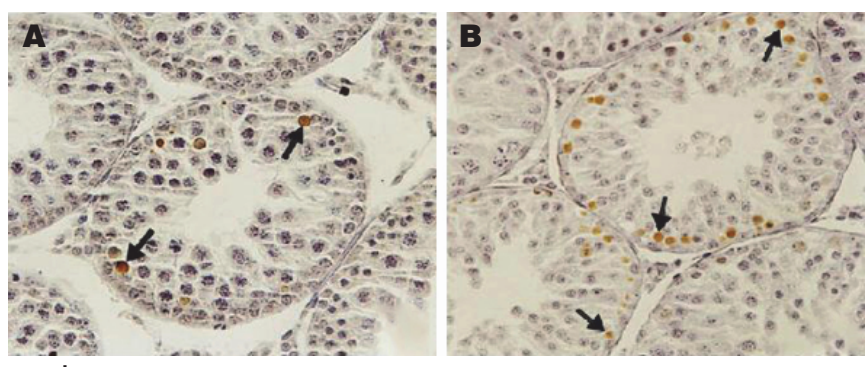

ŞEKiL 8. Etoposid uygulanan sıçanların primer spermatositlerindeki apoptosisin (TUNEL-pozitif) gösterimi (oklar). (A) $10 \mathrm{mg} / \mathrm{kg}$ etoposid uygulamasından 12 saat sonra dekapite edilen 26 günlük sıçanlardaki apoptotik hücre görünümü. (B) 40 mg/ kg etoposid uygulamasından 12 saat sonra dekapite edilen 32 günlük sıçanlardaki apoptotik hücre görünümü [Stumpp ve ark. (181)'nın çalışmasından alıntılanmıştır].

Glukokortikoidlerden olan deksametazon koçlarda serum ve sperma hyaluronidaz aktivitesini değiştirirken, sperma miktarı, sperm yoğunluğu ve motilitesinde önemli azalmalara neden olmaktadır (185). Dietilstilbestrol sıçanların absolut ve rölatif epididimis ağırlığında, sperm sayısı, motilitesi ve testosteron düzeylerinde önemli azalmalara yol açmaktadır (186). Prenatal dönemdeki sıçanlara aromataz inhibitörlerinin verilmesi sonucunda yetişkinlik dönemlerinde testiküler sperm sayısı ve günlük sperm üretiminde azalma, libido yetersizliği ve çiftleşme sonucu gebe kalan dişilerde preimplantasyon kayıpları meydana gelmektedir (187). Sağlıklı sıçanlarda tamoksifen uygulaması sperm sayısı ve motilitesinde önemli azalmalara (188), anormal sperm sayısında önemli artışlara ve seminifer tubullerde atrofiye neden olmaktadır (189). İmatinib uygulanan fare ve sıçanların sperm sayısı, motilitesi, Sertoli ve Leydig hücre sayısı, testosteron düzeyleri, testiküler spermatogenik hücrelerinde azalma, FSH ve LH düzeyleri ile anormal sperm oranlarında artış (190-192) ve infertilite (193) şekillenmektedir. Ancak bu gonadotoksik etkilerin geçici olduğu ve 
imatinib uygulamasının sona ermesiyle birçok parametrede normalleşme görüldüğü de ileri sürülmektedir (191-192). Fare seminifer tubullerinde interferon fazlalığı Sertoli hücre bozukluğu, germ hücre kaybı ve steriliteye neden olmaktadır (194). Interleukin-2 ise fare Leydig hücrelerini in vitro olarak bask1ladığından dolayı testosteron sentezinin güçlü bir inhibitörü olarak kabul edilmektedir (195).

\section{KEMOTERAPÖTIKLERIN ERKEK ÜREME SISTEMINDEKI YAN ETKILERINI ÖNLEMEYE VEYA AZALTMAYA YÖNELIK KORUYUCU STRATEJILER}

Yukarıda sunulan literatür bilgilere göre antikanser amacıyla kullanılan ilaçların büyük bir çoğunluğunun kanserli hastalarda veya sağlıklı deney hayvanlarında çok önemli reprodüktif yan etkilere neden olduğu açık bir şekilde görülmektedir. Bu yan etkilerin şiddeti, tedavi sonrası ortadan kalkma süresi veya kalıcılığı kullanılan antikanser ajana, dozuna ve süresine göre değişmektedir. Kemoterapötiklerin sperm üretimi üzerindeki yan etkilerini önleyebilecek/azaltabilecek ve tedaviden sonra gonadal fonksiyonları düzenleyebilecek stratejilerin geliştirilmesi özellikle genç kanserli hastalar için büyük önem taşımaktadır. Bu amaçla, pek çok metodolojik, biyokimyasal ve biyolojik yaklaşımlar gerek kanserli insanlarda gerek araştırma amacıyla sağlıklı deney hayvanlarında kullanılmakta olup yeni stratejilerin belirlenmesi amacıyla çalışmalar devam etmektedir (16). Bu yaklaşımlar kemoterapiye başlamadan önce, esnasında ve kemoterapi bittikten sonra kullanılabilmektedir (5). Bununla birlikte kanser veya hastalığın tipi, kullanılacak ajanın türü ve kemoterapi öncesi hastanın sperma kalitesi gibi faktörler koruyucu stratejilerle tedavi sonrası gonadal fonksiyonların normale dönüştürülmesi açısından önem arz etmektedir (196). Bu nedenle, kemoterapiden önce hastanın fiziki olarak testislerinin, laboratuvar olarak da spermasinin muayenesi ile birlikte gonadotropin ve testosteron hormon düzeyleri tespit edildikten sonra kemoterapi ve koruyucu yaklaşımlar uygulanmalıdır.

\section{Hormon uygulaması}

Koruyucu terapinin uygulanmaya başladığı ilk yıllarda daha çok biyolojik yollarla yan etkilerin giderilmesine çalışılmıştır. Kemoterapi ile azalan testosteron düzeylerinin arttırılması (14) ya da germ hücrelerindeki proliferasyonun minimalize edilmesi için hipotalamus-hipofiz-gonad ekseninin baskılanması amacryla kemoterapi öncesinde ve esnasında GnRH analogları, antagonistleri ve steroidler (testosteron, progestagenler) kullanılmıştır $(13,18,101)$. Rodentler hariç insan ve primatların infantil dönemlerinde gonadotropinler ve testosteronda meydana gelen artışları müteakip puberteye kadar düzeylerinin genellikle düşük ve stabil kaldığı "sessiz veya sakin dönem" olarak adland1rılan bir zaman peryodu bulunmaktadır. İşte bu dönemde gonadotropinler ve testosterondaki düşük düzeylere istinaden testislerde de aktivite çok düşmekte ve germ hücre proliferasyonu da minimum düzeylerde kalmaktadır. Kemoterapötik ajanlar daha çok hücreler proliferasyon safhasındayken etkili oldukları için bu dönemde germ hücreleri üzerindeki etkilerinin de çok düşük seviyede olacağı tahmin edilmektedir. Bu teoriye göre kemoterapi esnasında testislerdeki proliferatif aktiviteyi düşürmek amacıyla hipotalamus-hipofiz-gonad ekseninin baskılanması, kemoterapötiklerin germ hücreler üzerindeki sitotoksik etkilerinin azaltılması veya önlenmesi açısından faydalı olacaktır. Bununla birlikte sakin dönemde kanser tedavisi gören çocuklarda daha sonra gonadal hasarların şekillenmesi, bu dönemde testislerdeki aktivitenin gerçekten düşük olup olmadığı konusunda şüphe uyandırmaktadır. Bu şüphelere istinaden yapılan çalışmalarda sakin dönemdeki çocuklarda uyku esnasında bile pulzatil LH sekresyonunun olduğu, maymunlarda da germ hücre proliferasyonunun bu dönemde devam ettiği tespit edilmiştir (197). GnRH analogları, antagonistleri ve steroidlerle yapılan 7 klinik çalışmadan sadece bir tanesinde bu hormonların pozitif etkilere sahip olduğunun van der Kaaij ve ark. (101) ile Meistrich (16) tarafından yazılmış derlemelerde bildirilmesi, sakin dönemde testislerdeki aktivitenin düşük olmadığ1 şüphesini destekler mahiyettedir.

Öte yandan deney hayvanlarıyla yapılan çalışmalar, hormonların koruyuculuğu açısından insan ve primatlardaki çalışmalara göre daha olumlu sonuçlar sunmaktadır. Örneğin; siklofosfamidin fare testislerinde meydana getirdiği histopatolojik lezyonların GnRH analoğu ile (198), sıçan spermatogoniumlarında şekillendirdiği hasarın ise $\mathrm{GnRH}$ antagonisti ve antiandrojenlerle (199) önlenebildiği bildirilmektedir. Benzer şekilde GnRH analoğu löprorelinin, sıçanlarda doksorubisin (200) ve busulfan (201) uygulamalarının neden olduğu spermatogenesisteki hasarları da önleyebildiği iddia edilmektedir. Testosteron $(151,153)$, östradiol 17- $\beta$, kolesterol (151), antiöstrojenik aktiviteye sahip klomifen sitrat (202) ve GnRH (155) sıçanlarda prokarbazinin neden olduğu spermatogenik aksaklıkları ve steriliteyi önlemektedir. Reddy ve ark. (131) karboplatinin neden olduğu sıçanlardaki testiküler hasarın testosteronla kısmen düzeltilebildiğini tespit etmişlerdir. Son 10 yıl içerisinde yapılan çalışmalarda spermatogenesisin hızlanmasını ve gonadal fonksiyonların devamını sağlayan büyüme hormonunun (somatotropin) da kemoterapötiklerin erkek üreme sisteminde oluşturduğu yan etkilerin önlenmesinde etkili olduğu ortaya konmuştur. Satoh ve ark. (203) siklofosfamidin somatotropin geni çıkarılmış sıçanların testis ve spermatogenik hücrelerinde hasarlara neden olduğu, siklofosfamid ile birlikte somatotropin uygulanan sıçanlarda ise spermatosit sayısı ve motilitesinde önemli artışlar gözlendiğini bildirmiştir. Benzer şekilde somatotropinin metotreksatın da neden olduğu testiküler ve spermatogenik hasarları önleyebildiği gözlenmiştir $(204,205)$. Tüm bunlara rağmen farelerde sisplatin (206) ve siklofosfamid (207) tarafından oluşturulan testis ve spermatogenik hücrelerdeki deneysel hasarların $\mathrm{GnRH}$ analogları ile düzeltilemediği de bildirilmektedir. Kemoterapinin yan etkilerinin hormonlarla önlenmesine yönelik laboratuvar hayvanlarındaki çalışmalar ümit vericidir. Ancak insan gonadlarının bu hormonlara karşı hayvanlardan daha farklı yanıt vermesine bağlı olarak insanlardaki etkisinin yok denecek kadar az olmasından dolayı bu hormonlar, kemoterapötik kaynaklı testiküler hasarın önlenmesinde yetersiz kalmaktadir $(7,208)$.

Spermanın dondururularak saklanması (kriyoprezervasyon) Spermanın dondurularak saklanması insanlarla karşılaştırıldığında hayvanlarda çok uzun yıllardan beri başarılı olarak yapılmakta ve bu konuyla ilgili sperma üretim merkezleri kaliteli hayvanlardan alınan spermaları dondurarak tüm dünyaya pazarlamaktadır. Hayvanlardaki bu önemli gelişmenin asıl sebebi suni tohumlama (yapay dölleme)'nın insanlara göre uzun yıllardan beri rutin olarak uygulanması ve elbetteki hayvanların ekonomik amaçlı kullanılmasından kaynaklanmaktadır. İnsanlara yönelik sperm bankacılığı, intrasitoplazmik sperm enjeksiyonunun bulunması gibi yardımcı üreme tekniklerindeki hızlı gelişmeler, tüm erkeklerin hatta sperm sayısı ve motilitesi 
çok düşük olanların bile sperması dondurulacak muhtemel adaylar olarak değerlendirilmesine olanak sağlamaktadır $(15,209)$. Gonadotoksik kemoterapiden önce sperm bankacılığı aracılığılla spermanın dondurulması ve saklanması, kanserli genç hastalarda fertilitenin korunması için en güvenilir ve en etkili metot olarak karşımıza çıkmaktadır (5,7,12,15,18,101,196). Akut myeloid löykemili hastaların da içinde bulunduğu bir grup löykemili hastada kemoterapiden önce ve sonraki sperma kalitesi değerlendirilmiş ve hastaların kemoterapiye başlamadan önce ileriki dönemlerdeki fertilitelerini koruyabilmeleri için kesinlikle spermalarını dondurarak sperm bankalarında saklamaları tavsiye edilmiştir $(76,210)$. Öte yandan yapılan çalışmalarda kanserli erkeklerin tedaviden sonra dondurulmuş spermalarını asla kullanma ihtiyacı duymasalar bile sperm bankac1lığını kullanmalarının, kanserle psikolojik savaşta faydalı olacağ1 da bildirilmektedir $(211,212)$. Bununla birlikte \%37'sini çocuksuz erkeklerin oluşturduğu kanserli hastaların sadece \%24'ü sperm bankacılığını kullanmaktadırlar (211). Bu durumun sebepleri arasında sperm bankacılık işlemlerinin maliyeti, dondurulma işleminden sonra sperma kalitesinin düşmesi, dondurma ve invitro fertilizasyon işlemlerini yapacak kişilerin tecrübesi ile tıbbi, yasal ve etik durumlardaki sorunlara bağlı olarak hastaların yeterince bilgilendirilememesi gösterilmektedir (7). Kemoterapi almayı bekleyen genç erkeklerin \%67'si kemoterapiden sonra muhtemel infertil olacakları konusunda bilgilendirilmeleri (213) sonucunda sperm bankacılığını kullananların oranının \%51'lere kadar çıktığı (211) bildirilmektedir.

Sperma kriyoprezervasyon işlemi kemoterapiden önceki herhangi bir zamanda yapılabilmektedir (15). Bu amaçla genellikle iki günlük bir cinsel perhizden sonra hastalardan en az üç sperma örneği alınır. Eğer hasta normal yolla sperma veremiyorsa penil vibratör, elektroejakülasyon ya da testiküler sperm ekstraksiyon (TESE) yöntemleriyle sperma/sperm alınıp dondurulabilmektedir. Kemoterapiye başlamadan önce hastada azoospermi şekillenmişse TESE spermatozoon elde edilmesi için kullanılabilecek en uygun metottur (46). Spermanın dondurulması işlemi sperm kalite parametrelerine zarar vermekle (196) beraber insanlarda in vitro fertilizasyon/intrasitoplazmik sperm enjeksiyonu amacıyla dondurulmuş spermanın kullanılmasıyla elde edilen fertilizasyon ve gebelik oranlarındaki başarı oranları taze spermadaki kadar olmasa da tatmin edicidir (214). Kanserli hastalarda bu teknoloji ile \%72 oranında fertilizasyon ve \%50'lere yakın doğum oranları elde edilmiştir $(215,216)$. Öte yandan azoospermi şekillenmiş iki testiküler kanserli hastada TESE ile elde edilen spermatozoonlar başarılı bir şekilde dondurulmuş olmasına rağmen sadece bir hastanin spermleri ile intrasitoplazmik sperm enjeksiyonu sonucunda gebelik sağlanabilmiştir (46).

\section{Germ hücre ve testiküler dokunun kriyoprezervasyonu, transplantasyon ve in vitro maturasyon}

Çocukluk dönemindeki kanser vakalarının \%80'i genellikle tedavi edilebilmekte, ancak kemoterapinin yan etkilerine bağlı olarak çocukların 1/3'ü yetişkinlik dönemlerinde infertil veya şiddetli bir şekilde subfertil kalabilmektedirler. Günümüzde, pubertal dönemde iken kansere yakalanan her 5000 erkekten 1 'inin olgunluk çağında bu tür reprodüktif problemlerle karş1 karşıya kaldığı bildirilmektedir (217). Prepubertal testis spermatozoa üretemediği halde diploid germinal köken hücreleri içermektedir (218). Pek çok kemoterapötik ilaç uygulaması ise köken spermatogoniumların tamamen ölümü ile sonuçlandığ1 için, prepubertal dönemdeki kanserli erkeklerin spermatogonial hücrelerinin dondurularak saklanması, kemoterapiden sonra oto-, homo-(Şekil 9) veya kseno-transplantasyon (Şekil 10) işlemleri, hastaların gelecekteki spermatogenesisleri ile fertilitelerinin kurtarılması açısından göz önünde bulundurulması gereken önemli yöntemlerdir (219). Bu işlemler esnasında testisteki somatik hücrelerin de zarar görme ihtimalinden dolayı transplante edilen germ hücrelerinin testis tarafından desteklenememe durumu da göz ardı edilmemelidir (220).

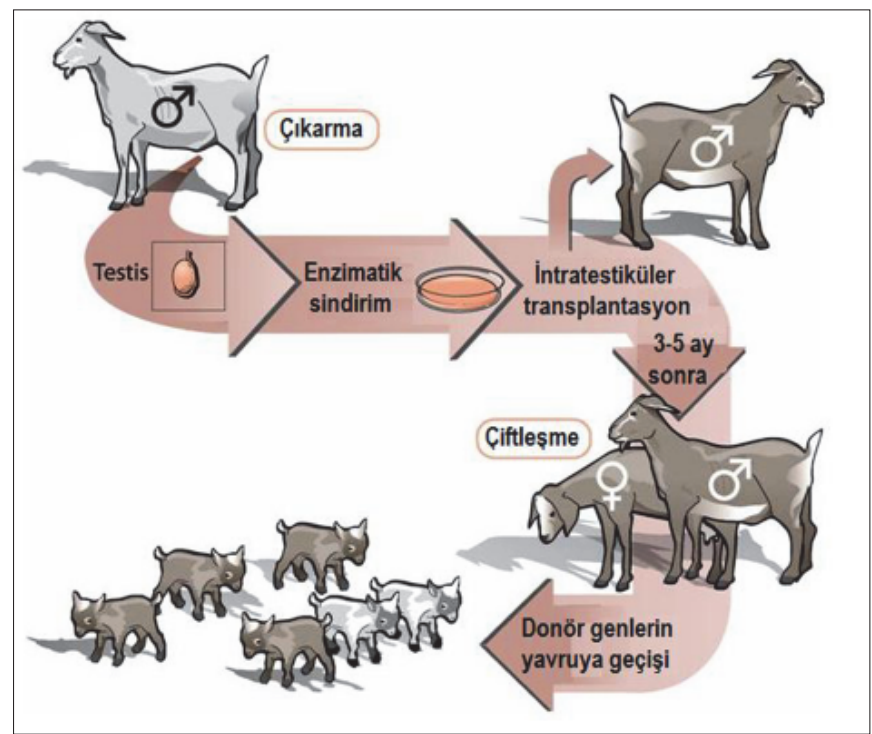

ŞEKiL 9. Testiküler homotransplantasyonun aşamaları [Honaramooz (221)'dan uyarlanmıştır].

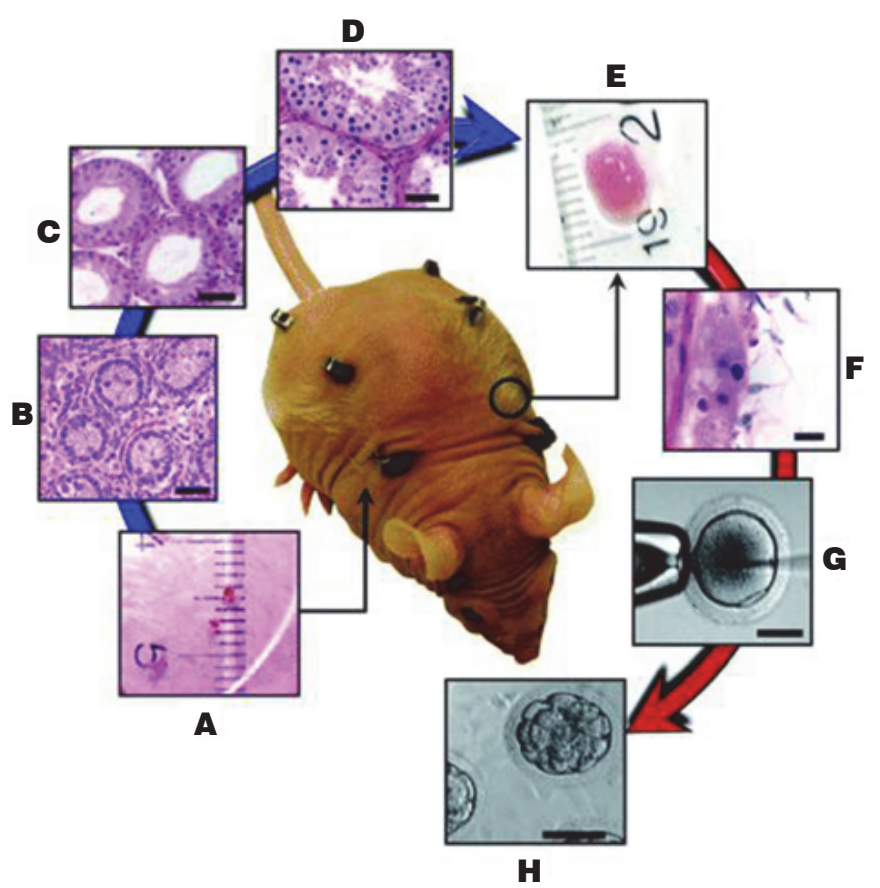

ŞEKiL 10. Büyükbaş hayvanlardan alınan olgunlaşmamış testisin immun sistem baskılanmış farelere ektopik ksenotransplantasyonu. $1 \mathrm{~mm}^{3}$ çapındaki olgunlaşmamış donör testisi (A ve $\mathbf{B})$, immun sistemi baskılanmış farenin derisi altına transplante edilir ve fare gonadotropinleri altında fertilizasyonu sağlayacak olgun bir sperm haline gelinceye kadar gelişmesini devam ettirir (C-F). Testiküler ksenogreftler toplanır toplanmaz (E), analiz, intrasitoplazmik sperm enjeksiyonu (G) ve embriyo üretimi (H) için kullanılabilir [Rodriguez-Sosa ve Dobrinski (237)'nin çalışmasından uyarlanmıştır]. 
Sperma kriyoprezervasyonuna alternatif olan germ hücre kriyoprezervasyon işlemi kemoterapiden önce hastada hiç sperm yoksa uygulanmakta olup çok fazla sayıda olgunlaşmamış hücre testiküler biyopsi veya aspirasyon yöntemleriyle elde edilebilmektedir. Bu teknikler kemoterapiden sonra yardımcı üreme teknikleri için taze spermleri toplamak amacıyla da kullanılmaktadır (222). Keros ve ark. (223)'nın yapmış olduğu bir çalışmada, gonadotoksik terapiden önce prepubertal kanserli çocukların olgunlaşmamış testislerinden alınan spermatogoniumlar, Sertoli ve stromal hücrelerin dimetilsulfoksit ile başarılı bir şekilde dondurulduğu ve fonksiyonlarını koruduğu bildirilmektedir. Benzer başka bir çalışmada 7-14 yaşlarındaki 5 erkekten biyopsi ile al1nan testiküler dokular dondurulup çözdürüldükten sonra 6 ay boyunca fare skrotum derisi altına transplante (ksenotransplantasyon) edilmiştir. Sonuçta testiküler dokunun yaklaşık \%50'sinde normal tubuler gelişme, sayısız premeyotik spermatosit, az sayıda pahiten spermatosit ve spermatid benzeri hücrelerin görülmesi ile birlikte apoptosisin olmadığı tespit edilmiştir (224). Öte yandan fare, sıçan, tavşan ve maymun gibi pek çok hayvan türünde homo-, oto- ve kseno-transplantasyon işlemleri ile tam bir spermatogenesis sağlanarak olgun spermler, hatta farelerde 14 yil boyunca dondurulan germ hücrelerinden fertilizasyon sonucu yavru bile başarılı bir şekilde elde edilmektedir (217). İnsan germ hücre ksenotransplantasyon uygulamaları üzerine yapılan çalışmalarda ise germ hüce proliferasyon safhasından daha öteye gidilememesinin ve hayvanlardaki gibi fertlizasyonla başarıya henüz ulaşılamamasının $(224,225)$ nedeni olarak germ hücrelerini destekleyen Sertoli hücrelerindeki türe-spesifik farklılıklar gösterilmektedir (197). Bu sorunun üstesinden gelmek için ikinci bir seçenek ise germ ve diğer destek hücrelerini ihtiva eden tüm testisin ektopik bölgelere transplantasyonudur. Konsept fareler üzerinde denenmesine rağmen (226) insanlardaki uygulamaların başarısı halen tartışılmaktadır $(226,227)$.

İnsanlar için deney aşamasında olan in vitro maturasyon da fertilitenin korunması açısından kanserli hastalarda alternatif bir yaklaşım olarak kabul edilmektedir. Spesifik kültürler yardımıyla hücrelerin in vitro farklılaşması sağlanarak insan germ hücrelerinin vitro maturasyonunun başarılması için araştırmalar devam etmektedir. Bu işlemle obstruktif olmayan azoospermili hastalarin spermatogonial germ hücreleri haploid germ hücrelerine kadar olgunlaştırılabilmektedir (228). Benzer şekilde, prepubertal hastalardan elde edilen testiküler dokunun 24 saat boyunca in vitro maturasyona birakılmasından sonra germ hücrelerinde herhangi bir yapısal hasarın şekillenmediği de gözlenmiştir (223). Yardımcı üreme teknolojileri sayesinde çok düşük düzeyde olgun sperm üretilebilse de bu tekniklerin kanserli hastaların çocuk sahibi olmalarında etkili olduğu düşünülmektedir.

\section{Antioksidan koruyucular}

Kemoterapötik ilaçların pek çoğu doğrudan olabildiği gibi testis ve spermada oksidatif strese yol açarak dolaylı yoldan da erkek üreme sisteminde gonadotoksik hasarlara neden olmaktadır. Bu ilaçların uygulanması sonucu ROS düzeylerinde artış ve antioksidanlarda da (GSH, GSH-Px, katalaz, vitamin A, E, C, çinko, melatonin ve sitokrom C) azalmalar meydana gelmektedir. Oksidanlar ve antioksidanlardaki dengesizlikler de testislerin hem steroidogenik hem de spermatogenik fonksiyonlarına zarar vererek hormonal değişiklikler ile spermlerde yapisal, fonksiyonel ve genetik bozukluklara neden olmaktadır (28). Parenteral veya oral yolla alınacak farklı yapı ve özellikteki antioksidan maddeler yardımıyla ROS düzeyleri azaltılıp, antioksidan aktiviteleri arttırılarak kemoterapötiklerin erkek üreme sisteminde oluşturduğu muhtemel yan etkiler azaltılmaya veya tamamen önlenmeye çalışılmaktadır.

Tamamlayıcı ve alternatif tıp son zamanlarda gerek sağlıklı gerekse de hasta insanlar tarafından oldukça yaygın bir şekilde kullanılmaktadır. Özellikle kanserli hastaların yaklaşık \%50'sinin alternatif tıp yöntemlerinden en azından birini kullandığı bildirilmektedir. Gerek antikanser gerekse de kemoprotektif özelliklerinden dolayı güçlü antioksidan vitamin, kimyasal madde ve bitkisel ürünler kanserli hastalar tarafından en yaygin olarak kullanılan alternatif tıp yöntemleri arasında yer almaktadır (229). Antioksidanların deney hayvanlarındaki kemoprotektif etkileri çok ümit verici olsa da insanlardaki etkilerinin hayvanlar kadar belirgin olmaması nedeniyle klinik yansıması henüz istenildiği gibi olamamıştır. Kemoterapötiklerin erkek üreme sistemi üzerindeki yan etkilerinin antioksidanlarla giderilmesine yönelik sayısız bilimsel araştırma bulunmaktadır. Örneğin; vitamin C (57) ve omega-3 ( $\omega$-3) yağ asidinin (58), azatiyoprinin neden olduğu testiküler atrofi, azalmış sperm sayısı, artmış morfolojik yapı bozukluğu, artmış DNA ve kromozomal hasarları azaltma ve/veya önlemede etkili oluğu bildirilmektedir. Folik ve folinik asit folat mekanizmasını (25), kafein (73), taurin (43) ve klorogenik asit (70) ise oksidan-antioksidan dengeyi düzenleyerek metotreksat tarafından oluşturulan testiküler ve spermatozoal toksisiteyi azaltabilmektedir.

Greyfurt (Citrus paradisi) (230-232), yeşil çay (Camellia sinensis) (88), sacaca diye adlandırılan ve Amazonlarda yetişen Croton cajucara (89) ile kurt üzümü veya mutluluk meyvesi olarak bilinen Lycium barbarum (81), japon eriği olarak tanınan Ginkgo biloba (83) gibi bitkisel ekstraktların güçlü antioksidan veya antimutajenik etkileriyle doksorubisin kaynaklı testiküler, spermatozoal ve mutajenik hasarların tamamının ya da bir kısminın önlenebildiği ileri sürülmektedir (Şekil 11). Benzer şekilde, flavanoidlerden ellajik asit (85), karotenoidlerden likopen (23), sentetik antibiyotiklerden doksisiklin (91), bir $\beta$-amino asit olan taurin (84) ve $\beta$-glukan (90) gibi kimyasal antioksidanların da bitkisel ekstraktlardaki gibi serbest radikal süpürücü etkileriyle doksorubisinin neden olduğu testis histolojisi, sperm kalite parametreleri (yoğunluk, motilite, anormalite) ve steroidogenesisteki hasarlar ile apoptotik germ hücre sayısındaki artışları önleyebildiği iddia edilmektedir.

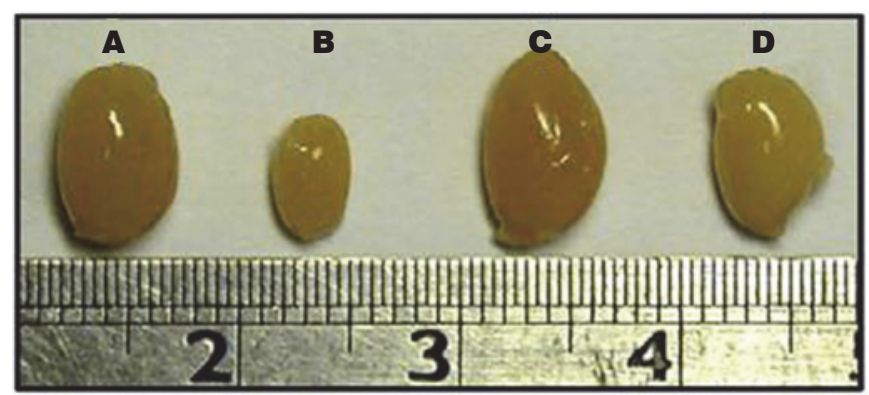

SEKiL 11. Kontrol (A), doksorubisin (B), doksisiklin (C) ve doksisiklin+doksorubisin (D) uygulanan farelerde testislerin morfolojik görüntüsü /Yeh ve ark. (91)'nın çalışmasından alıntılanmıştır]

Alkilleyici ajanlardan busulfan uygulaması ile farelerdeki sperm yoğunluğu, motilitesi, anormal sperm oranı, testosteron düzeyi ve apoptotik hücre sayısında gözlenen bozuklukların çok güçlü bir antioksidan olan melatoninle $(42,148)$, testiküler 


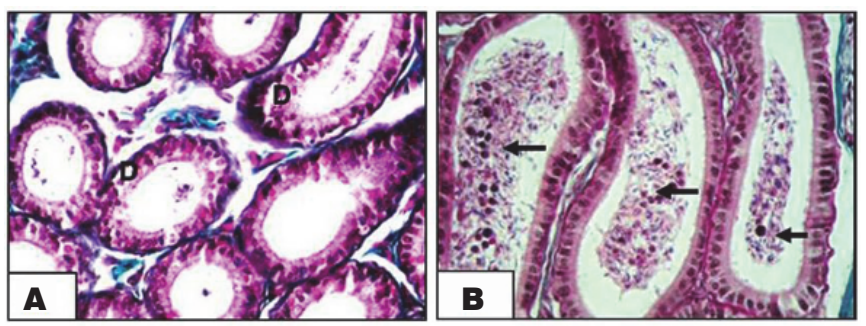

ŞEKiL 12. Sisplatin (A) ve sisplatin + L-askorbik asit (B) uygulanan farelerde epididimisin görünümü. Sisplatin uygulanan grupta epitelyal dejenerasyon $(D)$ ve spermatozoon yokluğu; sisplatin + L-askorbik asit uygulanan grupta yapısal bozukluklar olmamasına rağmen lümende olgunlaşmamış hücre varlığı (oklar) [Narayana (144)'nın çalışmasından alıntılanmıştır].

histopatolojik lezyonların ise Panax ginseng türevi olan protopanaxatriol saponinle (146) önlenebildiği gözlenmiştir. Sisplatin, alkilleyici ajanlar içerisinde maksimum yan etkiye sahip ilaçlardan biri olduğu için çok farklı yapıdaki antioksidanların koruyuculuğu (233) ile ilgili çalışmalar da bu kemoterapötik üzerinde daha fazla yoğunlaşmıştır. Bu çalışmalarda farklı deney hayvanlarında kullanilan melatonin $(22,121)$ L-askorbik asit (143) likopen $(21,27)$ ellajik asit $(27,132)$, curcumin $(140,234)$, arı sütü (133), nüklear faktör-kB inhibitörü, pirolidin ve ditiyokarbamat kombinasyonu (141), vitamin C, difenil-p-fenilendiamin (DPPD), L-sistein kombinasyonu (139), zencefil ve bamya çiçeği (137) Afrika kigelia bitkisi olarak bilinen Kigelia africana $(134,138)$ ve bir antienflamatuvar ajan olan montelukast (136) v.b. hormon, vitamin, kimyasal, bitkisel ve hayvansal ürünler sisplatin ile oluşturulan testis ve spermlerdeki yapısal, fonksiyonel, genetik bozukluklar ve testosterondaki azalmaları kısmen/tamamen azaltabilen veya önleyebilen güçlü antioksidan bileşikler olarak gösterilmektedir (Şekil 12).

Siklofosfamid gonadotoksisitesine karşı da melatonin (121), vitamin E (123), likopen, ellajik asit (Şekil 13) (26,122), lipoik asit $(235,236)$, çemen otu (128) ve bir kırmızı karotenoid pigmenti olan astaksantin (127) koruyucu antioksidanlar olarak görev yapabilmektedirler. Öte yandan folik asit, $B_{12}$ ve $C$ vitamini de ifosfamidin fare germ hücreleri üzerindeki mutajenik etkisini azaltabilmektedir $(41,117)$.

\section{Gelecekte uygulanması düşünülen tedaviler}

Tüm organ ve dokularda hücrelerin kaynağını oluşturan kök hücreler testiste de köken spermatogoniumlar şeklinde mevcuttur. Yardımcı üreme tekniklerinin çok ilerlediği günümüzde, pek çok hastalığın tedavisi için umut kaynağı olarak görünen kök hücre tedavisi, kanserli ve kemoterapi alacak genç erkeklerde de üreme potansiyellerinin korunması ve devamı için gelecekte uygulanabilirliği yüksek ve spermatogonial kök hücrelerin kullanıldığı tıbbi bir gelişme olarak karşımıza çıkmaktadır. Uygulanması düşünülen teknolojik gelişmelerden bir diğeri de embriyonik veya somatik kök hücrelerden sperm elde edilme yoluna gidilmesidir (218).

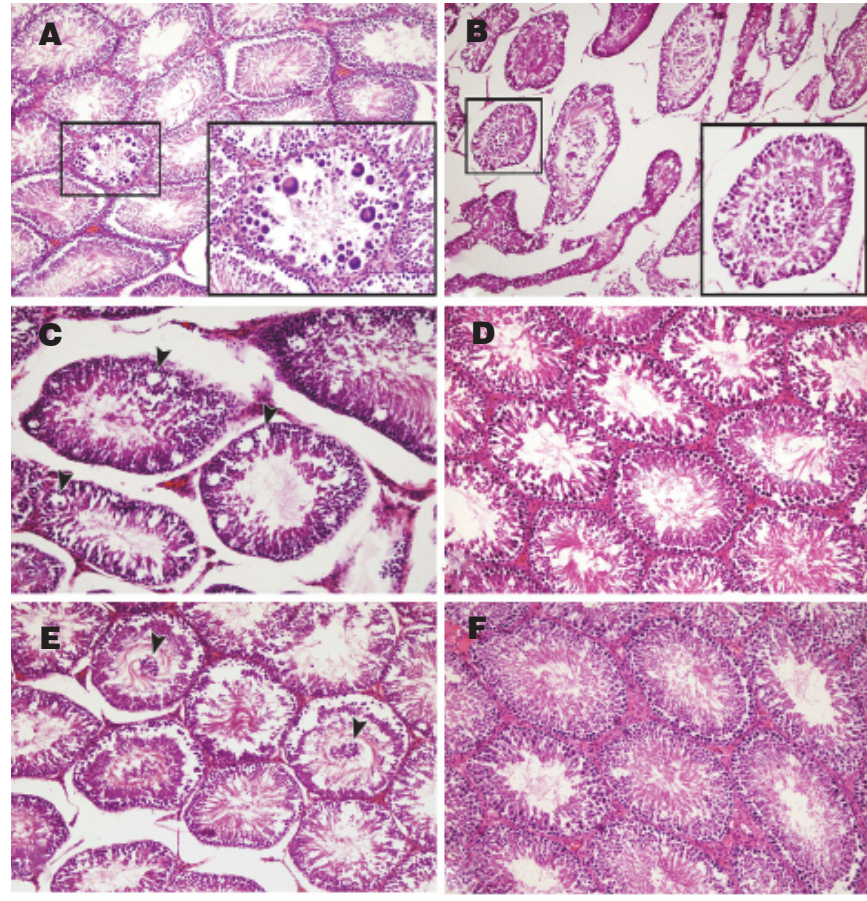

SEKiL 13. Siklofosfamid, likopen ve ellajik asit uygulanan gruplarda testislerin histopatolojik yapısındaki değişiklikler. Siklofosfamid uygulanan sıçanlarda çok çekirdekli dev hücre oluşumu (A), şiddetli nekroz (B) ve Sertoli hücrelerinde vakualizasyon (C). Siklofosfamid + likopen uygulanan gruptaki sıçanların testislerinde normale yakın çok önemli düzeyde iyileşmeler (D), Siklofosfamid + ellajik asit uygulanan grupta lümene dökülmüş germ hücreler ve intersitisyel ödemle birlikte orta düzeyde iyileşmeler tespit edilmiştir (E). Kontrol grubunda testislerin normal histolojik görüntüsü (F) [Çeribaşı ve ark. (122)'nın çalışmasından alıntılanmıştır].

\section{SONUÇ}

Antikanser ilaçların bulunması ve sürekli yeni ilaçların geliştirilmesi şüphesiz kanser hastalarının yaşam süresinin uzamasındaki en etkili faktörlerden biridir. Bununla birlikte bu ajanların üreme sisteminde meydana getirdiği yan etkiler erkeklerin cinsel ve fertil yaşam kalitesini olumsuz bir şekilde etkilemektedir. Bu konuyla ilgili kanserli erkekler ve sağlıklı deney hayvanlarında yapılan sayısız bilimsel çalışmanın sonuçları, özellikle genç erkeklerin gelecekteki fertilite potansiyellerinin ciddi bir tehlike içerisinde olduğunu ne yazık ki çok açık bir şekilde ortaya koymaktadır. Kemoterapötiklerin erkek üreme sistemindeki yan etkilerinin önlenmesine yönelik çeşitli hormon ve antioksidan uygulamalar ile sperma, germ hücre ve testis dokusunun dondurularak saklanması gibi yaklaşımlar deney hayvanlarında başarılı sonuçlar vermiş olsa da günümüz şartlarında kanserli erkeklerde kullanılabilirliği ve koruyuculuğu en yüksek yöntem sperma kriyoprezervasyonu olarak karşımıza çıkmaktadır. 


\section{Adverse effects of chemotherapeutics on male reproductive system, and protective strategies}

ABSTRACT: Although cytotoxic chemotherapy is an effective method for the treatment of many cancer types, it causes numerous adverse effects on the body. Infertility is also one of the most prominent side effects of chemotherapeutic drugs on both females and males. Impotence, oligo-, azoo-, asthenozoo- and teratozoo-spermia, disturbances in testicular structure, spermatogenesis and steroidogenesis, the changes in gonadotrophin levels, damages in sperm DNA and chromosomes, and even exact sterility are the reported side effects induced by chemotherapy in both males with cancer and healthy experimental animals. To prevent the gonadotoxic effects of chemotherapeutics in males, several modalities such as hormone and antioxidant administrations, sperm and germ cell cryopreservation are used. In this review, the data about the adverse effects induced by chemotherapeutics, which are commonly used in cancer treatment, in reproductive organ, tissue and cells in both males with cancer and healthy experimental animals and, also knowledge related to the preventive or protective strategies against these side effects are presented.

KEY WORDS: Antioxidant; chemotherapeutics; cryopreservation; oxidative stress; sperm; testis

\section{KAYNAKLAR}

1. Wright NA. Cell proliferation in carcinogenesis. In: The Cancer Handbook. Editor: MR Alison, Nature Publishing Group, London. 2002, pp. 114-25.

2. Boerner JL, Biscardi JS, Parsons SJ. Overview of oncogenesis. The Cancer Handbook. Editor: MR Alison, Nature Publishing Group, London. 2002, pp. 25-34.

3. Pizzo PA, Poplack DG. Principles and Practice of Pediatric Oncology. Lippincott: Williams \& Wilkins, Philadelphia. 2001.

4. Page R, Takimoto C. Principles of chemotherapy. In: Cancer Management: A Multidisciplinary Approach Medical, Surgical \& Radiation Oncology. Editors: R Pazdur, LR Coia, WJ Hoskins, LD Wagman. PRR, New York. 2004. pp. 21-38.

5. Sabanegh ES, Ragheb AM. Male fertility after cancer. Urology 2009;73:225-31.

6. Demirci U, Benekli M, Büyükberber S, Coşkun U. Late side effects of cancer therapy. Int $\mathrm{J}$ Hematol Oncol 2010;4:250-61.

7. Ragheb AM, Sabanegh ES. Male fertility-implications of anticancer treatment and strategies to mitigate gonadotoxicity. Anticancer Agents Med Chem 2010;10:92-102.

8. Sharlip ID, Jarow JP, Belker AM, Lipshultz LI, Sigman M, Thomas AJ, Schlegel PN, Howards SS, Nehra A, Damewood MD, Overstreet JW, Sadovsky R. Best practice policies for male infertility. Fertil Steril 2002;77:873-82.

9. World Health Organization. WHO laboratory manual for the examination of human semen and semen-cervical mucus interaction. Cambridge University Press, Cambridge. 1999, pp. 1-86.

10. Bokemeyer C, Schmoll HJ, van Rhee J, Kuczyk M, Schuppert F, Poliwoda H. Long-term gonadal toxicity after therapy for hodgkin's and non-hodgkin's lymphoma. Ann Hematol 1994;68:105-10.

11. Petersen PM, Giwercman A, Skakkebaek NE, Rorth M. Gonadal function in men with testicular cancer. Semin Oncol 1998;25:224-33.

12. Schrader $M$, Müller $M$, Straub B, Miller K. The impact of chemotherapy on male fertility: a survey of the biologic, basis and clinical aspects. Reprod Toxicol 2001;15:611-7.
13. Averette HE, Boike GM, Jarrell MA. Effects of cancer chemotherapy on gonadal function and reproductive capacity. CA Cancer J Clin 1990;4:199-209.

14. Meistrich ML. Restoration of spermatogenesis by hormone treatment after cytotoxic therapy. Acta Paediatr Suppl 1999;88:19-22.

15. Oktay K, Meirow D. Planning for fertility preservation before cancer treatment. Sex Reprod Menop 2007;5:17-22.

16. Meistrich ML. Male gonadal toxicity. Pediatr Blood Cancer 2009;53:261-6.

17. Delbes $G$, Hales BF, Robaire $B$. Toxicants and human sperm chromatin integrity. Mol Hum Reprod 2010;16:14-22.

18. Colpi GM, Contalbi GF, Nerva F, Sagone P, Piediferro G. Testicular function following chemo-radiotherapy. Eur J Obstet Gynecol Reprod Biol 2004;113(Suppl 1):S2-6.

19. Tempest HG, Ko E, Chan $P$, Robaire $B$, Rademaker A, Martin RH. Sperm aneuploidy frequencies analysed before and after chemotherapy in testicular cancer and Hodgkin's lymphoma patients. Hum Reprod 2008;23:251-8.

20. Agarwal A, Sekhon LH. The role of antioxidant therapy in the treatment of male infertility. Hum Fertil 2010;13:217-25.

21. Ateşşahin A, Karahan İ, Türk G, Gür S, Yı1maz S, Çeribaşı AO. Protective role of lycopene on cisplatin-induced changes in sperm characteristics, testicular damage and oxidative stress in rats. Reprod Toxicol 2006;21:42-7.

22. Ateşşahin $A$, Şahna E, Türk $G$, Çeribaşı $A O, Y_{1}$ lmaz $S$, Yüce A, Bulmuş Ö. Chemoprotective effect of melatonin against cisplatin-induced testicular toxicity in rats. J Pineal Res 2006;41:21-7.

23. Ateşşahin A, Türk G, Karahan İ, Yılmaz S, Çeribaşı AO, Bulmuş Ö. Lycopene prevents adriamycin-induced testicular toxicity in rats. Fertil Steril 2006;85(Suppl 1):1216-22.

24. Muslimovic A, Nyström $S$, Gao $Y$, Hammarsten $O$. Numerical Analysis of Etoposide Induced DNA Breaks. PLoS One 2009;4:e5859.

25. Padmanabhan $S$, Tripathi DN, Vikram A, Ramarao $P$, Jena GB. Methotrexate-induced cytotoxicity and genotoxicity in germ cells of mice: intervention of folic and folinic acid. Mutat Res 2009;673:43-52. 
26. Türk G, Çeribaşı AO, Sakin F, Sönmez M, Ateşşahin A. Antiperoxidative and anti-apoptotic effects of lycopene and ellagic acid on cyclophosphamide induced testicular lipid peroxidation and apoptosis. Reprod Fertil Dev 2010;22:587-96.

27. Türk G, Çeribaşı AO, Şahna E, Ateşşahin A. Lycopene and ellagic acid prevent testicular apoptosis induced by cisplatin. Phytomedicine 2011;18:356-61.

28. Aitken RJ, Roman SD. Antioxidant systems and oxidative stress in the testes. Oxid Med Cell Longev 2008;1:15-24.

29. Hess RA, de Franca LR. Spermatogenesis and cycle of the seminiferous epithelium. In: Molecular Mechanisms in Spermatogenesis. Editor: CY Cheng. Adv Exp Med Biol (Book Series) 2008;636:1-15.

30. Codrington AM, Hales BF, Robaire B. Exposure of male rats to cyclophosphamide alters the chromatin structure and basic proteome in spermatozoa. Hum Reprod 2007;22:1431-42.

31. Codrington AM, Hales BF, Robaire B. Chronic cyclophosphamide exposure alters the profile of rat sperm nuclear matrix proteins. Biol Reprod 2007;77:303-11.

32. Türk G, Aksu EH, Bozkurt T. Spermatozoon DNA's1 hasarı. FÜ Sağlık Bil Vet Derg 2006;20:85-95.

33. Tremellen $K$. Oxidative stress and male infertility-a clinical perspective. Hum Reprod Update 2008;14:243-58.

34. Johnson GD, Lalancette $C$, Linnemann AK, Leduc F, Boissonneault G, Krawetz SA. The sperm nucleus: chromatin, RNA, and the nuclear matrix. Reproduction 2011;141:21-36.

35. O'Flaherty C, Hales BF, Chan $P$, Robaire B. Impact of chemotherapeutics and advanced testicular cancer or hodgkin lymphoma on sperm deoxyribonucleic acid integrity. Fertil Steril 2010;94:1374-9.

36. Grenier L, Robaire B, Hales BF. Paternal exposure to cyclophosphamide affects the progression of sperm chromatin decondensation and activates a DNA damage response in the prepronuclear rat zygote. Biol Reprod 2010;83:195-204.

37. Agarwal A, Cocuzza M, Abdelrazik H, Sharma RK. Oxidative stress measurement in patients with male or female factor infertility. In: Handbook of Chemiluminescent Methods in Oxidative Stress Assessment. Editors: I Popov, G Lewin. Transworld Research Network, KeralaIndia. 2008. pp. 195-218.

38. Ford WCL. Regulation of sperm function by reactive oxygen species. Hum Reprod Update 2004;10:387-99.

39. Sanocka D, Kurpisz M. Reactive oxygen species and sperm cells. Reprod Biol Endocrinol 2004;2:12, (1-7).

40. Kothari S, Thompson A, Agarwal A, du Plessis SS. Free radicals: their beneficial and detrimental effects on sperm function. Indian J Exp Biol 2010;48:425-35.

41. Donya SM, Aly FA, Abo-Zeid MAM. Antigenotoxic efficacy of some vitamins against the mutagenicity induced by ifosfamide in mice. Nature Sci 2010;8:55-66.

42. Ghasemi FM, Faghani $M$, Khajehjahromi $S$, Bahadori M, Nasiri EE, Hemadi M. Effect of melatonin on proliferative activity and apoptosis in spermatogenic cells in mouse under chemotherapy. J Reprod Contracept 2010;21:79-94.
43. Alam SS, Hafiz NA, El-Rahim AHA. Protective role of taurine against genotoxic damage in mice treated with methotrexate and tamoxfine. Environ Toxicol Pharmacol 2011;31:143-52.

44. Dejaco $C$, Mittermaier $C$, Reinisch W, Gasche C, Waldhoer T, Strohmer H, Moser G. Azathioprine treatment and male fertility in inflammatory bowel disease. Gastroenterology 2001;121:1048-53.

45. Damani MN, Masters $V$, Meng MV, Burgess $C$, Turek $P$, Oates RD. Postchemotherapy ejaculatory azoospermia: fatherhood with sperm from testis tissue with intracytoplasmic sperm injection. J Clin Oncol 2002;20:930-6.

46. Sakamoto $H$, Oohta $M$, Inoue K, Fuji K, Fukagai T, Yoshida $\mathrm{H}$. Testicular sperm extraction in patients with persistent azoospermia after chemotherapy for testicular germ cell tumor. Int J Urol 2007;14:167-70.

47. Fossa SD, Magelssen $H$. Fertility and reproduction after chemotherapy of adult cancer patients: malignant lymphoma and testicular cancer. Ann Oncol 2004;15(Suppl 4): iv259-65.

48. Chatterjee R, Haines GA, Perera DM, Goldstone A, Morris ID. Testicular and sperm DNA damage after treatment with fludarabine for chronic lymphocytic leukaemia. Hum Reprod 2000;15:762-6.

49. Chatzidarellis E, Makrilia N, Giza L, Georgiadis E, Alamara C, Syrigos KN. Effects of taxane-based chemotherapy on inhibin B and gonadotropins as biomarkers of spermatogenesis. Fertil Steril 2010;94:558-63.

50. Norgard B, Pedersen L, Jacobsen J, Rasmussen SN, Sorensen HT. The risk of congenital abnormalities in children fathered by men treated with azathioprine or mercaptopurine before conception. Aliment Pharmacol Ther 2004;19:679-85.

51. Shamberger RC, Rosenberg SA, Seipp CA, Sherins RJ. Effects of high-dose methotrexate and vincristine on ovarian and testicular functions in patients undergoing postoperative adjuvant treatment of osteosarcoma. Cancer Treat Rep 1981;65:739-46.

52. Grunnet E, Nyfors A, Hansen KB. Studies on human semen in topical corticosteroid-treated and in methotrexate-treated psoriatics. Dermatologica 1977;154:78-84.

53. French AE, Koren $G$, Team $M$. Effect of methotrexate on male fertility. Can Fam Physician 2003;49:577-8.

54. Meistrich ML, Chawla $S P$, da Cunha MF, Johnson SL, Plager C, Papadopoulos NE, Lipshultz LI, Benjamin RS. Recovery of sperm production after chemotherapy for osteosarcoma. Cancer 1989;63:2115-23.

55. Thomson AB, Campbell AJ, Irvine DC, Anderson RA, Kelnar CJ, Wallace WH. Semen quality and spermatozoal DNA integrity in survivors of childhood cancer: a case-control study. Lancet 2002;360:361-7.

56. Doerksen T, Trasler JM. Developmental exposure of male germ cells to 5-azacytidine results in abnormal preimplantation development in rats. Biol Reprod 1996;55:1155-62.

57. Karawya FS, El-Nahas AF. The protective effect of vitamin $\mathrm{C}$ on azathioprine induced seminiferous tubular structural changes and cytogenetic toxicity in albino rats. Cancer Ther 2006;4:125-34. 
58. Elelaimy IA, Elfiky SA, Hassan AM, Ibrahim HM, Elsayad RI. Genotoxicity of anticancer drug azathioprine (Imuran): role of omega-3 ( $\omega-3)$ oil as protective agent. J Appl Pharmaceut Sci 2012;2:14-23.

59. D'Souza Urban JA, Narayana K. Induction of seminiferous tubular atrophy by single dose of 5- fluorouracil (5-FU) in wistar rats. Indian J Physiol Pharmacol 2001;45:87-94.

60. D'Souza Urban JA. Toxic effects of 5-fluorouracil on sperm count in wistar rats. Malaysian J Med Sci 2003;10:43-45.

61. Takizawa S, Horii I. Endocrinological assessment of toxic effects on the male reproductive system in rats treated with 5-fluorouracil for 2 or 4 weeks. J Toxicol Sci 2002;27: 49-56.

62. Mohammed BMA, Kheravii SKQ. Evaluation of genotoxic potential of Hypericum triquetrifolium extract in somatic and germ cells of male albino mice. Res Opin Anim Vet Sci 2011;1:231-9.

63. Generoso WM, Preston RJ, Brewen JG. 6-Mercaptopurine, an inducer of cytogenetic and dominant-lethal effects in premeiotic and early meiotic germ cells of male mice. Mutat Res 1975;28:437-47.

64. Russell LB, Hunsicker PR. Study of the base analog 6-mercaptopurine in the mouse specific-locus test. Mutat Res 1987;176:47-52.

65. Karl PI, Katz R, Daum F, Fisher SE. 6-mercaptopurine and spermatogenesis in the young rat. Dig Dis Sci 1991;36:1569-73.

66. Ligumsky M, Badaan $S$, Lewis $H$, Meirow D. Effects of 6-mercaptopurine treatment on sperm production and reproductive performance: a study in male mice. Scand J Gastroenterol 2005;40:444-9.

67. Meistrich ML, Finch $M$, da Cunha MF, Hacker U, Au WW. Damaging effects of fourteen chemotherapeutic drugs on mouse testis cells. Cancer Res 1982;42:122-31.

68. Johnson FE, Farr SA, Mawad M, Woo YCS. Testicular cytotoxicity of intravenous methotrexate in rats. J Surg Oncol 1994;55:175-8.

69. Serati Nouri H, Azarmi YA, Movahedin M. Effect of growth hormone on testicular dysfunction induced by methotrexate in rats. Andrologia 2009;41:105-10.

70. Vardı N, Parlakpınar H, Ateş B, Otlu A. Metotreksatın neden olduğu testiküler hasara karşı klorogenik asidin koruyucu etkileri. Türkiye Klinikleri J Med Sci 2010;30:507-13.

71. Işık A, Işılay L, Erdemli EA, Akbay C, Anafarta K. Sıçan testisinde metotreksat'in 1ş1k ve elektron mikroskop düzeyinde etkileri. Ank Ünv Tıp Fak Mec 1997;50:125-9.

72. Saxena $A K$, Dhungel $S$, Bhattacharya $S$, Jha $C B$, Srivastava AK. Effect of chronic low dose of methotrexate on cellular proliferation during spermatogenesis in rats. Arch Androl 2004;50:33-5.

73. Palo AK, Choudhury RC. Modulation of methotrexateinduced cytogenotoxicity in mouse spermatogonia and its transmission in the male germline by caffeine. Environ Toxicol Pharmacol 2006;21:254-9.

74. Padmanabhan $S$, Tripathi $D N$, Vikram A, Ramarao $\mathrm{P}$, Jena GB. Cytotoxic and genotoxic effects of methotrexate in germ cells of male swiss mice. Mutat Res 2008;655:59-67.
75. Sparreboom A, Nooter K, Verweij J. Mechanisms of action of cancer chemotherapeutic agents: antitumour antibiotics. In: The Cancer Handbook. Editor: MR Alison. Nature Publishing Group, London. 2002. pp. 1333-46.

76. Lemez P. Cryopreservation of sperm from patients with leukemia. Cancer 1999;86:2184-5.

77. Spermon JR, Ramos L, Wetzels AM, Sweep CG, Braat DD, Kiemeney LA, Witjes JA. Sperm integrity pre- and post-chemotherapy in men with testicular germ cell cancer. Hum Reprod 2006;21:1781-6.

78. Martin RH, Ernst S, Rademaker A, Barclay L, Ko E, Summers N. Analysis of sperm chromosome complements before, during, and after chemotherapy. Cancer Genet Cytogenet 1999;108:133-6.

79. Aly FA, Donya SM, Abo-Zeid MAM. The protective role of folic acid, vitamin B12 and vitamin C on the mutagenicity of the anticancer drug daunorubicin. Researcher 2009;1:16-26.

80. Saalu LC, Enye LA, Osinubi AA. An assessment of the histomorphometric evidences of doxorubicin-induced testicular cytotoxicity in wistar rats. Int J Med Medic Sci 2009;1:370-4.

81. Xin Y-F, You Z-Q, Gao H-Y, Zhou G-L, Chen Y-X, Yu J, Xuan YX. Protective effect of Lycium barbarum polysaccharides against doxorubicin-induced testicular toxicity in rats. Phytother Res 2012;26:716-21.

82. Trivedi PP, Kushwaha S, Tripathi DN, Jena GB. Evaluation of male germ cell toxicity in rats: correlation between sperm head morphology and sperm comet assay. Mutat Res 2010;703:115-21.

83. Yeh $Y-C$, Liu T-J, Wang L-C, Lee H-W, Ting C-T, Lee W-L, Hung CJ, Wang KY, Lai HC, Lai HC. A standardized sxtract of Ginkgo biloba suppresses doxorubicin-induced oxidative stress and p53-mediated mitochondrial apoptosis in rat testes. Br J Pharmacol 2009;156:48-61.

84. Das J, Ghosh J, Manna P, Sil PS. Taurine protects rat testes against doxorubicin-induced oxidative stress ss well ss p53, Fas and caspase 12-mediated apoptosis. Amino Acids 2012;42:1839-55.

85. Çeribaşı AO, Sakin F, Türk G, Sönmez M, Ateşşahin A. Impact of ellagic acid on adriamycin-induced testicular histopathological lesions, apoptosis, lipid peroxidation and sperm damages. Exp Toxicol Pathol 2012;64:717-24.

86. Zanetti RS, Maldonado EN, Aveldano MI. Doxorubicin affects testicular lipids with long-chain (C18-C22) and very long-chain (C24-C32) polyunsaturated fatty acids. Cancer Res 2007;67:6973-80.

87. Takahashi $H$, Tainaka $H$, Umezawa M, Tkeda K, Tanaka $\mathrm{H}$, Nishimune Y, Oshio S. Evaluation of testicular toxicology doxorubicin based on microarray analysis of testicular specific gene expression. J Toxicol Sci 2011;36:559-67.

88. Sato $K$, Sueoka $K$, Tanigaki R, Tajima $H$, Nakabayashi A, Yoshimura Y, Hosoi Y. Green tea extracts attenuate doxorubicin-induced spermatogenic disorders in conjunction with higher telomerase activity in mice. J Assist Reprod Genet 2010;27:501-8.

89. Caneguim BH, Serpeloni JM, Maciel MAM, de Syllos Colus IM, de Fatima Paccola Mesquita S. Reduction of DNA-damage by croton cajucara methanolic extract but not the testicular alterations induced by doxorubicin. J Med Plants Res 2011;5:3277-85. 
90. Tohamy AA, El-Ghor AA, El-Nahas SM, Noshy MM. $\beta$-glucan inhibits the genotoxicity of cyclophosphamide, adriamycin and cisplatin. Mutat Res 2003;541:45-53.

91. Yeh $Y-C$, Lai H-C, Ting C-T, Lee W-L, Wang L-C, Wang K-Y, Lai H-C, Liu T-J. Protection by doxycycline against doxorubicin-induced oxidative stress and apoptosis in mouse testes. Biochem Pharmacol 2007;74:969-80.

92. Geng J, Fan J, Jiang H-W, Fang Z-J, Wang $X$, Sun J-L, Ding Q, Chen G. Elevated serum soluble Fas ligand is a promising marker of testicular toxicity induced by epirubicin in rats. Toxicol Lett 2009;186:96-103.

93. Arrebola DFA, Novoa AV, Fernandez LAR, Roche LD. Comparison of the sprague dawley rats response against cyclophosphamide and bleomycin in the head sperm morphology assay. Ars Pharmaceut 2010;51:155-62.

94. Hansen PV, Sorensen D. Effect of vincristine or bleomycin on radiation-induced cell killing of mice spermatogonial stem cells: the importance of sequence and time interval. Int J Radiat Oncol Biol Phys 1991;20:339-41.

95. Yongguang G, Xuliang L, Guanghui W, et al. Influence of vincristine and dactinomycin on spermatogenetic cells of testes in juvenile rats. Chinese J Pediatr Surg 2002;23:454-7.

96. Siddik ZH. Mechanisms of cancer chemotherapeutic agents: DNA-interactive alkylating agents and antitumour platinum-based drugs. In: The Cancer Handbook. Editor: MR Alison. Nature Publishing Group, London. 2002. pp. 1295-313.

97. Marmor D, Grob-Menendez F, Duyck F, Delafontaine D. Very late return of spermatogenesis after chlorambucil therapy: case reports. Fertil Steril 1992;58:845-6.

98. Guesry MDP, Lenoir MDG, Broyer MDM. Gonadal effects of chlorambucil given to prepubertal and pubertal boys for nephrotic syndrome. J Pediatr 1978;92:299303.

99. Callis MDL, Nieto J, Vila A, Rende J. Chlorambucil treatment in minimal lesion nephrotic syndrome: A reappraisal of its gonadal toxicity. J Pediatr 1980;97:653-6.

100. Williams D, Crofton PM, Levitt G. Does ifosfamide affect gonadal function? Pediatr Blood Cancer 2008;50:347-51.

101. van der Kaaij MAE, van Echten-Arends J, Simons AHM, Kluin-Nelemans HC. Fertility preservation after chemotherapy for Hodgkin lymphoma. Hematol Oncol 2010;28:168-79.

102. Levy MJ, Stillman RJ. Reproductive potential in survivors of childhood malignancy. Pediatrician 1991;18:61-70.

103. Aslam I, Fishel S, Moore H, Dowell K, Thornton S. Fertility preservation of boys undergoing anti-cancer therapy: a review of the existing situation and prospects for the future. Hum Reprod 2000;15:2154-9.

104. Kenney LB, Laufer MR, Grant FD, Grier H, Diller L. High risk of infertility and long term gonadal damage in males treated with high dose cyclophosphamide for sarcoma during childhood. Cancer 2001;91:613-21.

105. Meistrich ML, Wilson G, Brown BW, da Cunha MF, Lipshultz LI. Impact of cyclophosphamide on long-term reduction in sperm count in men treated with combination chemotherapy for Ewing and soft tissue sarcomas. Cancer 1992;70:2703-12.
106. Socie G, Salooja N, Cohen A, Rovelli A, Carreras E, Locasciulli A, Korthof E, Weis J, Levy V, Tichelli A; Late Effects Working Party of the European Study Group for Blood and Marrow Transplantation. Nonmalignant late effects after allogeneic stem cell transplantation. Blood 2003;101:3373-85.

107. Ahmed SR, Shalet SM, Campbell RHA, Deakin DP. Primary gonadal damage following treatment of brain tumors in childhood. J Pediatr 1983;103:562-65.

108. Reiter WJ, Kratzik C, Brodowicz T, Haitel A, Pokorny A, Zielinski CC, Marberger M. Sperm analysis and serum follicle-stimulating hormone levels before and after adjuvant single-agent carboplatin therapy for clinical stage I seminoma. Urology 1998;52:117-9.

109. Ishikawa T, Kamidono S, Fujisawa M. Fertility after high-dose chemotherapy for testicular cancer. Urology 2004;63:137-40.

110. De Mas P, Daudin M, Vincent MC, Bourrouillou G, Calvas P, Mieusset R, Bujan L. Increased aneuploidy in spermatozoa from testicular tumour patients after chemotherapy with cisplatin, etoposide and bleomycin. Hum Reprod 2001;16:1204-8.

111. Martin RH, Ernst S, Rademaker A, Barclay L, Ko E, Summers N. Analysis of human sperm karyotypes in testicular cancer patients before and after chemotherapy. Cytogenet Cell Genet 1997;78:120-3.

112. Gerl A, Mühlbayer D, Hansmann G, Mraz W, Hiddemann $W$. The impact of chemotherapy on Leydig cell function in long term survivors of germ cell tumors. Cancer 2001;91:1297-303.

113. Sanders JE, Hawley J, Levy $W$, Gooley $T$, Buckner CD, Deeg HJ, Doney K, Storb R, Sullivan K, Witherspoon R, Appelbaum FR. Pregnancies following high-dose cyclophosphamide with or without high-dose busulfan or total-body irradiation and bone marrow transplantation. Blood 1996;87:3045-52.

114. Generoso WM, Witt KL, Cain KT, Hughes L, Cacheiro NLA, Lockhart AMC, Shelby MD. Dominant lethal and heritable translocation tests with chlorambucil and melphalan in male mice. Mutat Res 1995;345:167-80.

115. Barnett LB, Lewis SE. Chlornaphazine and chlorambucil induce dominant lethal mutations in male mice. Mutat Res 2003;543:145-54.

116. Ypsilantis $P$, Papaioannou N, Psalla D, Politou M, Simopoulos C. Effects of single dose administration of ifosfamide on testes and semen characteristics in the rabbit. Reprod Toxicol 2003;17:237-45.

117. Donya SM, Aly FA, Abo-Zeid MAM. The protective role of folic acid, vitamin B12 and vitamin C on the mutagenicity of the anticancer drug ifosfamide. J Genet Engineer Biotechnol 2009;7:41-50.

118. Russell LB, Hunsicker PR, Cacheiro NL, Rinchik EM. Genetic, cytogenetic, and molecular analyses of mutations induced by melphalan demonstrate high frequencies of heritable deletions and other rearrangements from exposure of postspermatogonial stages of the mouse. Proc Natl Acad Sci USA 1992;89:6182-6.

119. Cordelli E, Fresegna AM, D'Alessio A, Eleuteri $P$, Spano M, Pacchierotti F, Villani P. ReProComet: a new in vitro method to assess DNA damage in mammalian sperm. Toxicol Sci 2007;99:545-52. 
120. Goldstein LS. Dominant lethal mutations induced in mouse spermatogonia by mechlorethamine, procarbazine and vincristine administered in 2-drug and 3-drug combinations. Mutat Res 1987;191:171-6.

121. İlbey YÖ, Özbek E, Şimşek A, Ötünçtemur A, Çekmen M, Somay A. Potential chemoprotective effect of melatonin in cyclophosphamide- and cisplatin-induced testicular damage in rats. Fertil Steril 2009;92:1124-32.

122. Çeribaşı AO, Türk $G$, Sönmez $M$, Sakin $F$, Ateşşahin A. Toxic effect of cyclophosphamide on sperm morphology, testicular histology and blood oxidant-antioxidant balance, and protective roles of lycopene and ellagic acid. Basic Clin Pharmacol Toxicol 2010;107:730-6.

123. Ghosh D, Das UB, Misro M. Protective role of a-tocopherol-succinate (provitamin-E) in cyclophosphamide induced testicular gametogenic and steroidogenic disorders: a correlative approach to oxidative stress. Free Radic Res 2002;36:1209-18.

124. Codrington AM, Hales BF, Robaire B. Spermiogenic germ cell phase-specific DNA damage following cyclophosphamide exposure. J Androl 2004;25:354-62.

125. Aguilar-Mahecha $A$, Hales BF, Robaire B. Effects of acute and chronic cyclophosphamide treatment on meiotic progression and the induction of DNA double-strand breaks in rat spermatocytes. Biol Reprod 2005;72:1297-304.

126. Elangovan N, Chiou T-J, Tzeng W-F, Chu S-T. Cyclophosphamide treatment causes impairment of sperm and its fertilizing ability in mice. Toxicology 2006;222:60-70.

127. Tripathi DN, Jena GB. Astaxanthin inhibits cytotoxic and genotoxic effects of cyclophosphamide in mice germ cells. Toxicology 2008;248:96-103.

128. Sakr SA, Mahram HA, El-Yazid SMA. Effect of fenugreek seeds extracton cyclophosphamide-induced histomorphometrical, ultrastructural and biochemical changes in testes of albino mice. Toxicol Indust Health 2012;28:27688.

129. Ehling UH, Adler ID, Favor J, Neuhauser-Klaus A. Induction of specific-locus and dominant lethal mutations in male mice by 1,3-bis(2-chloroethyl)-1-nitrosourea (BCNU) and 1-(2-chloroethyl)-3-cyclohexyl-1-nitrosourea (CCNU). Mutat Res 1997;379:219-31.

130. Reddy YVK, Reddy PS, Shivalingam MR, Devi BS, Pravallika CNNS, Anusha DN. Carboplatin-mediated changes in the activity levels of steroidogenic marker enzymes, serum hormones and testicular architecture in male rats. Drug Invent Today 2010;2:42-8.

131. Reddy YVK, Reddy PS, Shivalingam MR. Testosterone mediated partial recovery of carboplatin induced reproductive toxicity in male wistar rats. J Biomed Sci Res 2010;2:46-53.

132. Türk $G$, Ateşşahin $A$, Sönmez $M$, Çeribaşı AO, Yüce A. Improvement of cisplatin-induced injuries to sperm quality, the oxidant-antioxidant system, and the histologic structure of the rat testis by ellagic acid. Fertil Steril 2008;89(5 Suppl):1474-81.

133. Silici S, Ekmekcioglu O, Eraslan G, Demirtaş A. Antioxidative effect of royal jelly in cisplatin-induced testes damage. Urology 2009;74:545-51.
134. Azu OO, Duru FIO, Osinubi AA, Oremosu AA, Noronha CC, Elesha SO, Okanlawon AO. Histomorphometric effects of kigelia africana (bignoniaceae) fruit extract on the testis following short-term treatment with cisplatin in male sprague-dawley rats. Mid East Fertil Soc J 2010;15:200-8.

135. Çiftçi O, Beytur A, Çakır O, Gürbüz N, Vardı N. Comparison of reproductive toxicity caused by cisplatin and novel platinum-n-heterocyclic carbene complex in male rats. Basic Clin Pharmacol Toxicol 2011;109:328-33.

136. Beytur A, Ciftci O, Oguz F, Oguzturk H, Yilmaz F. Montelukast attenuates side effects of cisplatin including testicular, spermatological, and hormonal damage in male rats. Cancer Chemother Pharmacol 2012;69:207-13.

137. Amin A, Hamza AA, Kambal A, Daoud S. Herbal extracts counteract cisplatin-mediated cell death in rat testis. Asian J Androl 2008;10:291-7.

138. Azu OO, Duru FIO, Osinubi AA, Oremosu AA, Norohna CC, Okanlawon AO, Elesha SO. Long-term treatment with kigelia africana fruit extract ameliorates the testicular toxicity following cisplatin administration in male sprague-dawley rats. J Med Plants Res 2011;5:388-97.

139. Ahmed EA, Omar HM, El-Ghaffar SKhA, Ragb SMM, Nasser AY. The antioxidant activity of vitamin C, DPPD and L-cysteine against cisplatin-induced testicular oxidative damage in rats. Food Chem Toxicol 2011;49:1115-21.

140. İlbey YÖ, Özbek E, Çekmen M, Şimşek A, Ötünçtemur A, Somay A. Protective effect of curcumin in cisplatininduced oxidative injury in rat testis: mitogen-activated protein kinase and nuclear factor-kappa B signaling pathways. Hum Reprod 2009;24:1717-25.

141. İlbey YÖ, Özbek E, Şimşek A, Çekmen M, Ötünçtemur A, Somay A. Chemoprotective effect of a nuclear factor-kB inhibitor, pyrrolidine dithiocarbamate, against cisplatininduced testicular damage in rats. J Androl 2009;30:505-14.

142. Favareto APA, Fernandez CDB, da Silva DAF, AnselmoFranci JA, Kempinas WDG. Persistent impairment of testicular histology and sperm motility in adult rats treated with cisplatin at peri-puberty. Basic Clin Pharmacol Toxicol 2011;109:85-96.

143. Narayana K, Verghese $S$, Jacob SS. L-ascorbic acid partially protects two cycles of cisplatin chemotherapy-induced testis damage and oligo-astheno-teratospermia in a mouse model. Exp Toxicol Pathol 2009;61:553-63.

144. Narayana K. Cisplatin induces duplex 3 ' overhangs and 5 ' blunt ends in epididymal epithelium in a Bax-dependent manner without any protection from L-ascorbic acid. Eur J Pharmacol 2010;641:238-45.

145. Anjamrooz SH, Movahedin M, Mowla SJ, Bairanvand SP. Assessment of morphological and functional changes in the mouse testis and epididymal sperms following busulfan treatment. Iranian Biomed J 2007;11:15-22.

146. Ji M, Minami $N$, Yamada $M$, Imai $H$. Effect of protopanaxatriol saponin on spermatogenic stem cell survival in busulfan-treated male mice. Reprod Med Biol 2007;6:99-108.

147. Perez-Crespo M, Pericuesta E, Perez-Cerezales $S$, Arenas MI, Lobo MVT, Diaz-Gil JJ, Guiterrez-Adan A. Effect of liver growth factor on both testicular regeneration and recovery of spermatogenesis in busulfan-treated mice. Reprod Biol Endocrinol 2011;9:21. 
148. Ghasemi FM, Faghani M, Karkan FM. The protective effect of melatonin on sperm parameters, epididymis and seminal vesicle morphology in adult mouse treated with busulfan. J Iranian Anat Sci 2010;8:25-36.

149. Bucci LR, Meistrich ML. Effects of busulfan on murine spermatogenesis: cytotoxicity, sterility, sperm abnormalities, and dominant lethal mutations. Mutat Res 1987;176:259-68.

150. Kumar SG, Narayana K, Bairy KL, D'Souza UJ, Samuel VP, Gopalakrishna K. Dacarbazine induces genotoxic and cytotoxic germ cell damage with concomitant decrease in testosterone and increase in lactate dehydrogenase concentration in the testis. Mutat Res 2006;607:240-52.

151. Parchuri N, Wilson G, Meistrich ML. Protection by gonadal steroid hormones against procarbazine-induced damage to spermatogenic function in LBNF1 hybrid rats. J Androl 1993;14:257-66.

152. Johnson FE, Doubek WG, Tolman KC, Janney CG. Testicular cytotoxicity of intravenous procarbazine in rats. Surg Oncol 1993;2:77-81.

153. Delic JI, Bush C, Peckham MJ. Protection from procarbazine-induced damage of spermatogenesis in the rat by androgen. Cancer Res 1986;46:1909-14.

154. Velez de la Calle JF, Soufirt JCI, Chodorget F, Boisseau CI, Kercret H, Jegou B. Reproductive effects of the anticancer drug procarbazine in male rats at different ages. J Reprod Fertil 1988;84:51-61.

155. Ward JA, Robinson J, Furr BJA, Shalet SM, Morris ID. Protection of spermatogenesis in rats from the cytotoxic procarbazine by the depot formulation of zoladex, a gonadotropin-releasing hormone agonist. Cancer Res 1990;50:568-74.

156. Horstman MG, Meadows GG, Yost GS. Separate mechanisms for procarbazine spermatotoxicity and anticancer activity. Cancer Res 1987;47:1547-50.

157. Singh H, Kozel T, Jackson S. Effect of procarbazine on sperm morphology in syrian hamsters. J Toxicol Environ Health 1989;27:107-21.

158. Dancey J, Arbuck S. Cancer drugs and cancer drug development for the new millennium. In: Progress in Anti-cancer Chemotherapy. Editors: D Khayat, GN Hortobagyi. Springer, France, Berlin, Heidelberg. 2000. pp. 91-107.

159. Gobello C, Corrada Y. Effects of vincristine treatment on semen quality in a dog with a transmissible venereal tumour. J Small Anim Pract 2002;43:416-7.

160. Saratsis $\mathrm{PH}$, Ypsilantis $P$, Tselkas K. Semen quality during vincristine treatment in dogs with transmissible venereal tumor. Theriogenology 2000;53:1185-92.

161. Palo AK, Pandit RS, Choudhury RC. Vinblastine-induced cytogenotoxicity in spermatogonia and its transmission in the germline cells of swiss mice. J Environ Pathol Toxicol Oncol 2011;30:113-21.

162. Dobrzynska MM, Czajka U, Slowikowska MG. Reproductive effects after exposure of male mice to vincristine and to a combination of X-rays and vincristine. Reprod Fertil Dev 2005;17:759-67.

163. Sonawane T, Chaudhari $N$, Udani J, Thayyil L, Bhiwgade DA. Alteration in testicular protein profile following administration of embelin and vincristine: potent reproductive toxicants. J Cell Tis Res 2011;11:2815-20.
164. Averal HI, Stanley A, Murugaian P, Palanisamy M, Akbarsha MA. Specific effect of vincristine on epididymis. Indian J Exp Biol 1996;34:53-6.

165. Zhang Y, Sun K. Unscheduled DNA synthesis induced by the antitumor drug vincristine in germ cells of male mice. Mutat Res 1992;281:25-9.

166. Dobrzynska MM, Slowikowska MG, Mikulska U. The change in reproductive ability of male mice exposed to vinblastine and X-rays. Rocz Panstw Zakl Hig 2004;55:147-57.

167. Koehler-Samouilidou G, Kaldrymidou E, Papaioannou N, Kotsaki-Kovatsi VP, Vadarakis A. The effect of paclitaxel (taxol) on the reproductive system and the semen parameters as well as on other organs of male rats. J Hellenic Vet Med Soc 2001;52:23-31.

168. Gerres L, Bramswig JH, Schlegel W, Jurgens H, Schellong G. The effects of etoposide on testicular function in boys treated for Hodgkin's disease. Cancer 1998;83:2217-22.

169. Bush LA, Herr JC, Wolkowicz M, Sherman NE, Shore A, Flickinger CJ. A novel asparaginase-like protein is a sperm autoantigen in rats. Mol Reprod Develop 2002;62:233-47.

170. Pryzant RM, Meistrich ML, Wilson G, Brown B, McLaughlin P. Long-term reduction in sperm count after chemotherapy with and without radiation therapy for non-Hodgkin's lymphomas. J Clin Oncol 1993;11:239-47.

171. Mancini RE, Lavieri JC, Muller F, Andrada JA, Saraceni DJ. Effect of prednisolone upon normal and pathologic human spermatogenesis. Fertil Steril 1966;17:500-13.

172. Koyun M, Baysal $Y E$, Usta MF, Akman $S$, Güven AG. Evaluation of reproductive functions in male adolescents following renal transplantation. Pediatr Transplant 2009;13:697-700.

173. Raman JD, Schlegel PN. Aromatase inhibitors for male infertility. J Urol 2002;167:624-9.

174. Meriggiola MC, Bremner WJ, Costantino A, Di Cintio G, Flamigni C. Low dose of cyproterone acetate and testosterone enanthate for contraception in men. Hum Reprod 1998;13:1225-9.

175. Seshadri T, Seymour JF, McArthur GA. Oligospermia in a patient receiving imatinib therapy for the hypereosinophilic syndrome. N Engl J Med 2004;351:2134-5.

176. Mariani $S$, Basciani $S$, Fabbri A, Agati L, Ulisse S, Lubrano C, Spera G, Gnessi L. Severe oligozoospermia in a young man with chronic myeloid leukemia on long-term treatment with imatinib started before puberty. Fertil Steril 2011;95:1120.e15-7.

177. Schilsky RL, Davidson HS, Magid D, Daiter S, Golomb HM. Gonadal and sexual function in male patients with hairy cell leukemia: lack of adverse effects of recombinant alpha 2-interferon treatment. Cancer Treat Rep 1987;71:179-81.

178. Longo I, Sanchez-Mateos $P$, Lazaro P, Longo N. Azoospermia in a patient receiving interferon alpha for a stage III melanoma. Acta Derm Venereol 2002;82:389-90.

179. Pecou S, Moinard N, Walschaerts M, Pasquier C, Daudin M, Bujan L. Ribavirin and pegylated interferon treatment for hepatitis $C$ was associated not only with semen alterations but also with sperm deoxyribonucleic acid fragmentation in humans. Fertil Steril 2009;91:933.e17-22. 
180. Bian SL, Jin HB, Wang SZ, Zhang HF, Gu CR, Zhang W, Yu XG. Effects of interferon-gamma and tumor necrosis factor-alpha on the fertilizing capacity of human sperm and their mechanisms. Zhonghua Nan Ke Xue, 2007;13:681-4.

181. Stumpp T, Sasso-Cerri E, Freymüller E, Miraglia SM. Apoptosis and testicular alterations in albino rats treated with etoposide during the prepubertal phase. Anat Rec A 2004;279(A):611-2.

182. Freitas FEL, Mori FC, Cerri ES, Lucas SRR, Miraglia SM. Alterations in spermatogenesis in etoposide-treated rats: a stereological study. Interciencia 2002;27:227-35.

183. Palo AK, Sahu P, Choudhury RC. Etoposide-induced cytogenotoxicity in mouse spermatogonia and its potential transmission. J Appl Toxicol 2005;25:94-100.

184. Marchetti F, Pearson FS, Bishop JB, Wyrobek AJ. Etoposide induces chromosomal abnormalities in mouse spermatocytes and stem cell spermatogonia. Hum Reprod 2006;21:888-95.

185. Gür S, Bozkurt T, Türk G. Short term effects of dexamethasone on hyaluronidase activity and sperm characteristics in rams. Anim Reprod Sci 2005;90:255-63.

186. Goyal HO, Braden TD, Mansour M, Williams CS, Kamaleldin A, Srivastava KK. Diethylstilbestrol-treated adult rats with altered epididymal sperm numbers and sperm motility parameters, but without alterations in sperm production and sperm morphology. Biol Reprod 2001;64:927-34.

187. Gerardin DCC, Pereira OCM. Reproductive changes in male rats treated perinatally with an aromatase inhibitor. Pharmacol Biochem Behav, 2002;71:301-5.

188. Motrich RD, Ponce AA, Rivero VE. Effect of tamoxifen treatment on the semen quality and fertility of the male rat. Fertil Steril 2007;88:452-61.

189. D'Souza Urban JA. Effect of tamoxifen on spermatogenesis and tubular morphology in rats. Asian J Androl, 2004;6:223-6.

190. Yaghmaei P, Parivar K, Gharibi A, Nabiuni M. The biological effects of imatinib on male fertility of wistar rats. Int J Fertil Steril 2009;3:135-42.

191. Prasad M, Ramnarayan K, Bairy KL. Effect of imatinib on the reproductive function in male swiss albino mice. Pharmacologyonline 2010;1:469-78.

192. Prasad M, Ramnarayan $K$, Bairy KL. Effect of imatinib on histological parameters in male swiss albino mice. Int J Pharmaceut Sci Rev Res 2010;4:117-22.

193. Nurmio M, Kallio J, Toppari J, Jahnukainen K. Adult reproductive functions after early postnatal inhibition by imatinib of the two receptor tyrosine kinases, c-kit and PDGFR, in the rat testis. Reprod Toxicol 2008;25:442-6.

194. Satie AP, Mazaud-Guittot $S$, Seif I, Mahe D, He Z, Jouve G, Jegou B, Dejucq-Rainsford N. Excess type I interferon signaling in the mouse seminiferous tubules leads to germ cell loss and sterility. J Biol Chem 2011;286:23280-95.

195. Meikle AW, Cardoso de Sousa JC, Dacosta N, Bishop DK, Samlowski WE. Direct and indirect effects of murine interleukin-2, gamma interferon, and tumor necrosis factor on testosterone synthesis in mouse leydig cells. J Androl 1992;13:437-43.
196. Trottmann M, Becker AJ, Stadler T, Straub J, Soljanik I, Schlenker B, Stief CG. Semen quality in men with malignant diseases before and after therapy and the role of cryopreservation. Eur Urol 2007;52:355-67.

197. Mitchell RT, Saunders PTK, Sharpe RM, Kelnar CJH, Wallace WHB. Male fertility and strategies for fertility preservation following childhood cancer treatment. Endocr Dev 2009;15:101-34.

198. Glode LM, Robinson J, Gould SF. Protection from cyclophosphamide-induced testicular damage with an analogue of gonadotropin releasing hormone. Lancet 1981;1:1132-4.

199. Meistrich ML, Parchuri N, Wilson G, Kurdoglu B, Kangasniemi M. Hormonal protection from cyclophosphamide-induced inactivation of rat stem spermatogonia. J Androl 1995;16:334-41.

200. Manabe F, Takeshima $H, A$ kaza $H$. Protecting spermatogenesis from damage induced by doxorubicin using the luteinizing hormone-releasing hormone agonist leuprorelin: an image analysis study of a rat experimental model. Cancer 1997;79:1014-21.

201. Udagawa $K$, Ogawa $T$, Watanabe $T$, Yumura $Y$, Takeda M, Hosaka M. GnRH analog, leuprorelin acetate, promotes regeneration of rat spermatogenesis after severe chemical damage. Int J Urol 2001;8:615-22.

202. Weissenberg $R$, Lahav $M$, Raanani $P$, Singer $R$, Regev $A$, Sagiv M, Giler S, Theodor E. Clomiphene citrate reduces procarbazine-induced sterility in a rat model. Br J Cancer 1995;71:48-51.

203. Satoh $K$, Ohyama $K$, Nakagomi $Y$, Ohta $M$, Shimura $Y$, Sano T, Ishikawa H, Amemiya S, Nakazawa S. Effects of growth hormone on testicular dysfunction induced by cyclophosphamide (CP) in GH-deficient rats. Endocr J 2002;49:611-9.

204. Afshin KA, Serati Nouri H, Azarmi YA, Nouri M, Khaki AA, Roushangar L. Survey of growth hormone effects on methotrexate side effects in rat testis. Scientific J Hamadan Univ Med Sci Health Serv 2007;14:40-7.

205. Afshin KA. Effect of growth hormone on testicular dysfunction and apoptosis induced by methotrexate in rats. Yakhteh 2008;10(Suppl 1):41.

206. Nonomura M, Okada K, Hida S, Yoshida O. Does a gonadotropin-releasing-hormone analog prevent cisplatininduced spermatogenic impairment? An experimental study in the mouse. Urol Res 1991;19:135-40.

207. da Cunha MF, Meistrich ML, Nader S. Absence of testicular protection by a gonadotropin-releasing hormone analogue against cyclophosphamide-induced testicular cytotoxicity in the mouse. Cancer Res 1987;47:1093-7.

208. Shetty G, Meistrich ML. Hormonal approaches to preservation and restoration of male fertility after cancer treatment. J Natl Cancer Inst Monogr 2005;34:36-9.

209. Lee SJ, Schover LR, Partridge AH, Patrizio P, Wallace WH, Hagerty K, Beck LN, Brennan LV, Oktay K; American Society of Clinical Oncology. American society of clinical oncology recommendations on fertility preservation in cancer patients. J Clin Oncol 2006;24:2917-31.

210. Hallak J, Kolettis PN, Sekhon VS, Thomas AJ Jr, Agarwal A. Cryopreservation of sperm from patients with leukemia. Is it worth the effort? Cancer 1999;85:1973-8. 
211. Schover LR, Brey K, Lichtin A, Lipschultz LI, Jeha S. Knowledge and experience regarding cancer, infertility, and sperm banking in younger male survivors. J Clin Oncol 2002;20:1880-9.

212. Saito K, Suzuki K, Iwasaki A, Yumura $Y$, Kubota $Y$. Sperm cryopreservation before cancer chemotherapy helps in the emotional battle against cancer. Cancer 2005;104:521-4.

213. Edge B, Holmes $D$, Makin G. Sperm banking in adolescent cancer patients. Arch Dis Child 2006;91:149-52.

214. Wald M, Ross LS, Prins GS, Cieslak-Janzen J, Wolf G, Niederberger CS. Analysis of outcomes of cryopreserved surgically retrieved sperm for IVF/ICSI. J Androl 2006;27:60-65.

215. Neal MS, Nagel $K$, Duckworth J, Bissessar H, Fischer MA, Portwine C, Tozer R, Barr RD. Effectiveness of sperm banking in adolescents and young adults with cancer: a regional experience. Cancer 2007;110:1125-9.

216. van Casteren $N J$, van Santbrink $E J$, van Inzen $W$, Romijn JC, Dohle GR. Use rate and assisted reproduction technologies outcome of cryopreserved semen from 629 cancer patients. Fertil Steril 2008;90:2245-50.

217. $\mathrm{Wu} X$, Goodyear SM, Abramowitz LK, Bartolomei MS, Tobias JW, Avarbock MR, Brinster RL. Fertile offspring derived from mouse spermatogonial stem cells cryopreserved for more than 14 years. Hum Reprod 2012;27:1249-59.

218. Dohle GR. Male infertility in cancer patients: review of the literature. Int J Urol 2010;17:327-31.

219. Orwig KE, Schlatt S. Cryopreservation and transplantation of spermatogonia and testicular tissue for preservation of male fertility. J Natl Cancer Inst Monogr 2005;34:51-6.

220. Zhang $Z$, Shao $S$, Meistrich $M$. The radiation-induced block in spermatogonial differentiation is due to damage to the somatic environment, not the germ cells. J Cell Physiol 2007;211:149-58.

221. Honaramooz A. Cryopreservation of testicular tissue. In: Current Frontiers in Cryobiology. Editor: II Katkov. InTech, California. 2012. pp. 209-28.

222. Hovatta O. Cryopreservation of testicular tissue in young cancer patients. Hum Reprod Update 2001;7:378-83.

223. Keros V, Hultenby $K$, Borgström B, Fridstrom M, Jahnukainen $\mathrm{K}$, Hovatta O. Methods of cryopreservation of testicular tissue with viable spermatogonia in pre-pubertal boys undergoing gonadotoxic cancer treatment. Hum Reprod 2007;22:1384-95.

224. Wyns $C$, Langendonckt $A V$, Wese F-X, Donnez J, Curaba $M$. Long-term spermatogonial survival in cryopreserved and xenografted immature human testicular tissue. Hum Reprod 2008;23:2402-14.
225. Nagano $M$, Patrizio $P$, Brinster RL. Long-term survival of human spermatogonial stem cells in mouse testes. Fertil Steril 2002;78:1225-33.

226. Geens M, De Block G, Goossens E, Frederickx V, Van Steirteghem A, Tournaye H. Spermatogonial survival after grafting human testicular tissue to immunodeficient mice. Hum Reprod 2006;21:390-6.

227. Schlatt S, Honaramooz A, Boiani $M$, Scholer HR, Dobrinski I. Progeny from sperm obtained after ectopic grafting of neonatal mouse testes. Biol Reprod 2003;68:2331-5.

228. Lee DR, Kim KS, Yang YH, Oh HS, Lee SH, Chung TG, Cho JH, Kim HJ, Yoon TK, Cha KY. Isolation of male germ stem cell-like cells from testicular tissue of nonobstructive azoospermic patients and differentiation into haploid male germ cells in vitro. Hum Reprod 2006;21:471-6.

229. Klempner SJ, Bubley G. Complementary and alternative medicines in prostate cancer: from bench to bedside? Oncologist 2012;17:830-7.

230. Saalu L, Kpela T, Shittu LAJ, Ashiru OA. Grapefruit seed extract moderates morphologic, functional and biochemical evidences of epidoxorubicin-induced testicular toxicity. J Med Sci 2007;7:650-4.

231. Saalu L, Osinubi AA, Jewo PI, Oyewopo AO, Ajayi GO. An evaluation of influence of citrus paradisi seed extract on doxorubicin-induced testicular oxidative stress and impaired spermatogenesis. Asian J Sci Res 2010;3:51-61.

232. Saalu L, Osinubi AA, Oguntpla JA, Adeneye IO, Benebo AS. The delayed testicular morphologic effects of doxorubicin and the rejuvinating role of grapefruit seed extract. Int J Pharmacol 2010;6:192-9.

233. Sabuncuoglu $S$, Özgüneş H. Sisplatin toksisitesi: oksidatif stresin önemi ve antioksidanların etkisi. İst Tıp Fak Derg 2011;74:18-25.

234. Kandemir FM, Benzer F, Yildirim NC, Ozdemir N. Compensatory effects of curcumin on cisplatininduced toxicity in rabbit testis. J Med Plants Res 2011;5:456-61.

235. Selvakumar E, Prahalathan C, Mythili $Y$, Varalakshmi P. Beneficial effects of DL-a-lipoic acid on cyclophosphamide-induced oxidative stress in mitochondrial fractions of rat testis. Chem Biol Interact 2005;152:59-66.

236. Selvakumar E, Prahalathan C, Sudharsan PT, Varalakshmi P. Chemoprotective effect of lipoic acid against cyclophosphamide-induced changes in the rat sperm. Toxicology 2006;217:71-8.

237. Rodriguez-Sosa JR, Dobrinski I. Recent developments in testis tissue xenografting. Reproduction 2009;138:187-94. 